\title{
Spatial variability of selected physicochemical parameters within peat deposits in small valley mire: a geostatistical approach
}

\author{
Dominik Pawłowski ${ }^{1{ }^{*}}$, Daniel Okupny ${ }^{2}$, Wojciech Włodarski ${ }^{1}$, \\ Tomasz Zieliński ${ }^{1}$
}

\begin{abstract}
${ }^{1}$ Adam Mickiewicz University, Institute of Geology, Faculty of Geographical and Geological Sciences, Maków Polnych 16, 61-606 Poznań, Poland;

${ }^{2}$ Pedagogical University of Cracow, Institute of Geography, Podchorążych 2, 30-084 Kraków, Poland; *corresponding author, e-mail: dominikp@amu.edu.pl
\end{abstract}

\begin{abstract}
Geostatistical methods for 2D and 3D modelling spatial variability of selected physicochemical properties of biogenic sediments were applied to a small valley mire in order to identify the processes that lead to the formation of various types of peat. A sequential Gaussian simulation was performed to reproduce the statistical distribution of the input data ( $\mathrm{pH}$ and organic matter) and their semivariances, as well as to honouring of data values, yielding more 'realistic' models that show microscale spatial variability, despite the fact that the input sample cores were sparsely distributed in the $X-Y$ space of the study area. The stratigraphy of peat deposits in the Ldzań mire shows a record of long-term evolution of water conditions, which is associated with the variability in water supply over time. Ldzan is a fen (a rheotrophic mire) with a through-flow of groundwater. Additionally, the vicinity of the Grabia River is marked by seasonal inundations of the southwest part of the mire and increased participation of mineral matter in the peat. In turn, the upper peat layers of some of the central part of Ldzań mire are rather spongy, and these peat-forming phytocoenoses probably formed during permanent waterlogging.
\end{abstract}

Keywords: peat, geostatistics, organic matter, $\mathrm{pH}$, spatial analysis

\section{Introduction}

Many environmental variables-biological, chemical and physical-related to peats can be described in terms of spatiotemporal processes. Modelling their distribution is essential in many environmental sciences (Atkinson \& Lloyd, 2009; Hengl, 2009; Gao et al., 2012). Peatlands are special areas of interest for future climate change, because their influence on atmospheric composition is significant and is linked with atmospheric $\mathrm{CO}_{2}$ and $\mathrm{CH}_{4}$ concentrations (Clymo et al., 1998; Korhola et al., 2010). Peatland modelling is thus becoming increasingly popular in studies of peat bogs (e.g.,
Clymo, 1978; Ingram, 1982; Yu, et al., 2001; Borren \& Bleuten, 2004, 2014). Spatial peat accumulation reconstructions have generally been performed in ombrotrophic peatlands of Scandinavia (Korhola et al., 1996; Mäkilä \& Moisanen, 2007), Scotland (Chapman et al., 2009), Canada (Bauer et al., 2003; Beilman et al., 2008; Van Bellen et al., 2011), and Siberia (Sheng et al., 2004; Borren \& Bleuten, 2006).

Geostatistics provide a wide range of analytical tools for the spatial interpolation or simulation of environmental variables at unsampled locations (Isaaks \& Srivastava, 1989; Webster \& Oliver, 2007). The kriging methods of interpolation are based on minimising error variance algorithms (Goovaerts, 
1999), and the resulting models thus show smoothed local variation of estimates, where small values of the observed sample data can be overestimated in resultant models and high values may be underestimated. In turn, geostatistical simulation methods focus on the reproduction of the observed statistics in the resulting models, rather than on minimising local error variance. By reproducing the statistical distribution and semivariance of the observed data, as well as by honouring the data values, we can obtain more 'realistic' models (Goovaerts, 2000, 2001). Such models show a microscale spatial variability, although the input sample data can be sparsely distributed throughout the study area. For this reason, geostatistical simulation is preferred for applications where spatial microscale variability must be preserved. There are many examples of such applications in soil science (Lin et al., 2001; Cardellini et al., 2003; He et al., 2010) and geological modelling (Olea et al., 2010; Dell' Arciprete et al., 2012, Charifo et al., 2013; Ruggeri et al., 2014). Recently, the geostatistical modelling of biogenic sediments has focused on thickness variability (Saito et al., 2005; Keaney et al., 2013), facies modelling (Weerts \& Bierkens, 1993; Bos et al., 2012), groundwater level fluctuations (Cohen, 2005, Pniewski et al., 2012), and spatial distribution of some other variabilities (Blodau \& Moore, 2003; Parsekian et al., 2011). In spite of numerous studies focusing on geostatistical modelling of different environmental variables, there are no similar studies concerning the 3D spatial variability of physicochemical parameters in valley mire sediments. The present work proposes relatively novel approaches for determining and estimating spatiotemporal hydrological changes within the mire sediments.

One goal of the present study is to evaluate the spatial variability of selected physicochemical parameters within peat deposits in a small valley mire using the sequential Gaussian simulation method. This is the most common analytical method in geostatistics, and can be performed with $2 \mathrm{D}$ and 3D spatial modelling (Deutsch \& Journel, 1992; Remy et al., 2009). Valley mires in small river valleys, such as the Ldzań mire in the Grabia River, seem to be appropriate for such modelling. Fens in river valleys allow us to reconstruct ongoing processes in the region (Forysiak et al., 2010; Pawłowski et al., 2012), as valley mires are sensitive to changes in humidity, including drainage (Tobolski, 2003). High water tables create favorable conditions for the accumulation of organic sediments in groundwater-fed wetlands. Significant changes in water conditions lead to diversification of types of accumulated traces.
Ldzań mire is located very close (100-200 m) to the present-day Grabia River channel. Thus, flood records should be visible in its sediment, such as an evident increase of mineral matter. However, preliminary geological research has not confirmed the presence of sand layers within the peat succession. Therefore, we decided to apply a more 'sensitive' analysis tool to determine discrete changes of mineral matter content. We will also try to assess the degree of silting depending of the section examined, the type of deposits and degree of decomposition of organic matter using the similarity index of structures. Moreover, this analysis should help determine how far the record of flood waters reach, and whether the river had a significant impact on water supply of this mire, or not.

The regular shape and small area of the Ldzan mire seems to be suitable for the study of these relationships, because of the minimisation of some negative effects associated with the 3D geostatistical modelling based on data sampled at various horizontal and vertical scales. This is the most common problem in reservoir modelling, where data are obtained from sparsely distributed well logs (Pyrcz \& Deutsch, 2014). In our case, the sparse and irregular data sampling in the horizontal direction is related here to the limited number and spatial distribution of the Instorf corers. In turn, the vertical sampling of data is regular and defined only by sampling density of the corers. The small study area allows to reduce differences in the scale of data sampling and thus to obtain more reliable geostatistical models describing the spatial variability of physicochemical parameters in the horizontal direction. It was assumed here that the size and geometry of the Ldzań mire might facilitate recognition of complete depositional succession of various types of sediments. The differentiation of the physicochemical characteristics of sediments, the presence of admixtures of mineral matter, and the degree of decomposition of peat records finer (episodic) changes in water conditions. In the present work, we focused on modelling the spatial variation of ash content, organic matter $(\mathrm{OM}), \mathrm{pH}, \mathrm{CaCO}_{3}$, and the degree of peat decomposition, with special reference to reconstruction of the mire's development. All these parameters may serve as indicators of hydrological changes in the mire's environment and in the type of water supply. They may also indirectly illustrate the succession of vegetation and ecological development. An analysis of OM allows a more objective description of the lithology of deposits and of the interpretation of temporal changes in environmental dynamics. We used also the degree of decomposition of the peat to confirm possible hydrological 
changes in the mire. Additionally, we chose only these simple characteristic properties of peat, and especially $\mathrm{pH}$ and $\mathrm{OM}$, because these parameters are easily obtained from biogenic sediments.

A variability analysis of physicochemical properties of peat is often based on a single, deep core. The results obtained in this way can be statistically non-representative for the scale of the entire studied ecosystem. For this reason, we propose to reconstruct the spatial distribution patterns based on multiple cores from one mire. The results obtained from the geostatistical modelling show more detailed spatiotemporal hydrological changes within the mire environment controlled by climate change and human activity. Therefore, an additional goal of the present study is to introduce spatial analysis tools (2D and 3D modelling) to Polish research of mires and peats.

\section{Material and methods}

\subsection{Study site}

Ldzań is located in the central part of the Polish lowlands, in the Łódź area (Fig. 1A), near the town of Łask. The mire is located on the outer part of the valley floor and occupies an abandoned palaeochannel zone (Fig. 1B, 2A). The study site lies in the middle reach of the Grabia River and covers an area about of $0.044 \mathrm{~km}^{2}$. The Grabia is a natural, mostly unregulated river, inflowing to the Widawka, a tributary of the Odra (Oder). The neighbouring area was covered by the last ice sheet during the Warthian Stadial of the Saalian Glaciation (Klatkowa, 1987). Warthian till is present on the surrounding plains (Fig. 2A-B); locally it is overlain by glaciofluvial gravelly sands. Two terraces are distinguished

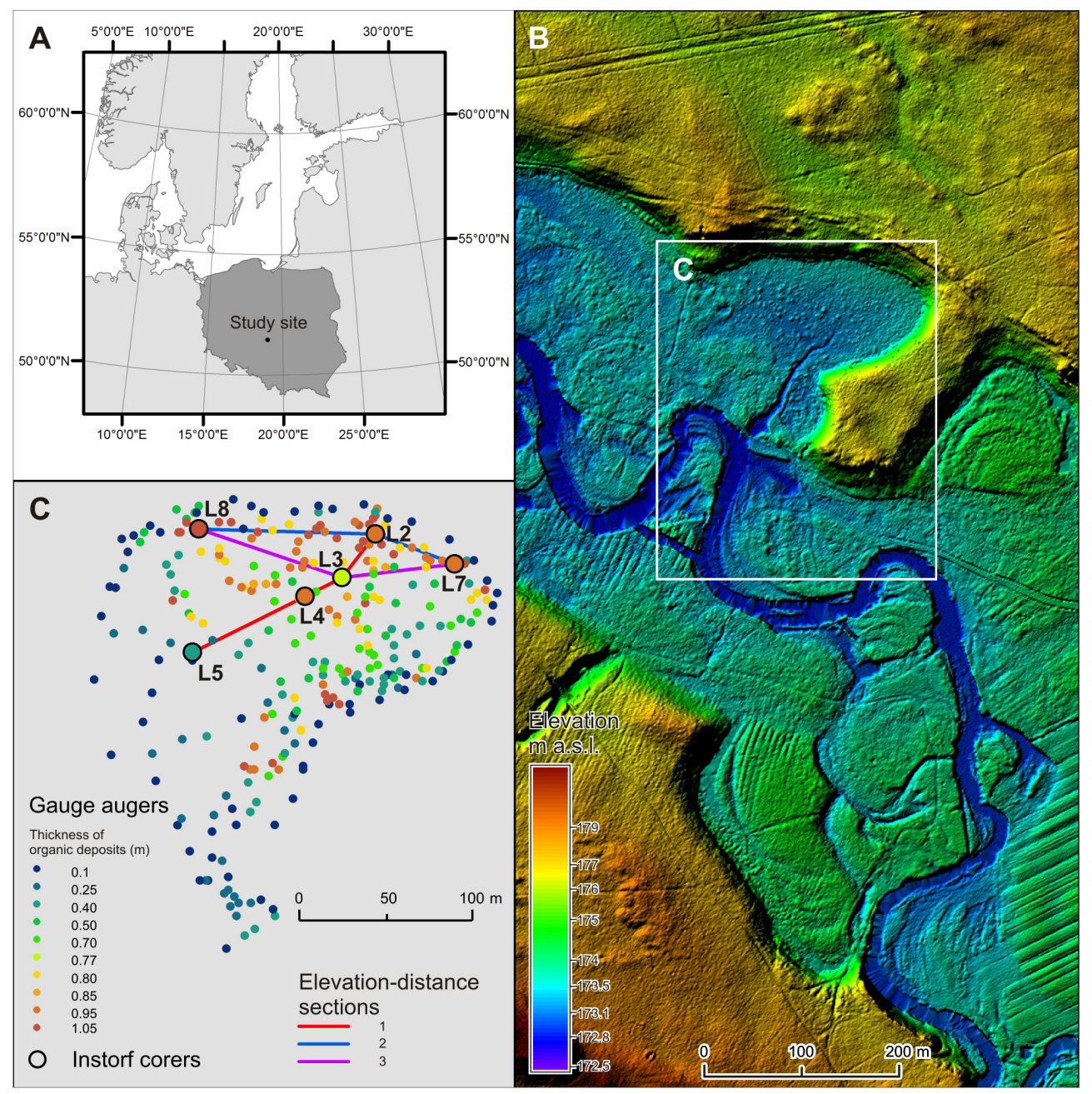

Fig. 1. A - Position of the Ldzań mire within Europe and Poland; B - LiDAR -based Digital Elevation Model (DEM) showing detailed morphology of the Grabia River valley; C - Irregular network of core data obtained from gauge augers and Instorf corers. Note that the Instorf corers in Fig. 1C are networked by three elevation-distance sections illustrated in Fig. 9 for which geostatistical modelling was performed. For simplification, the thickness of the organic deposits sampled by all core data is reclassified into decile ranges 


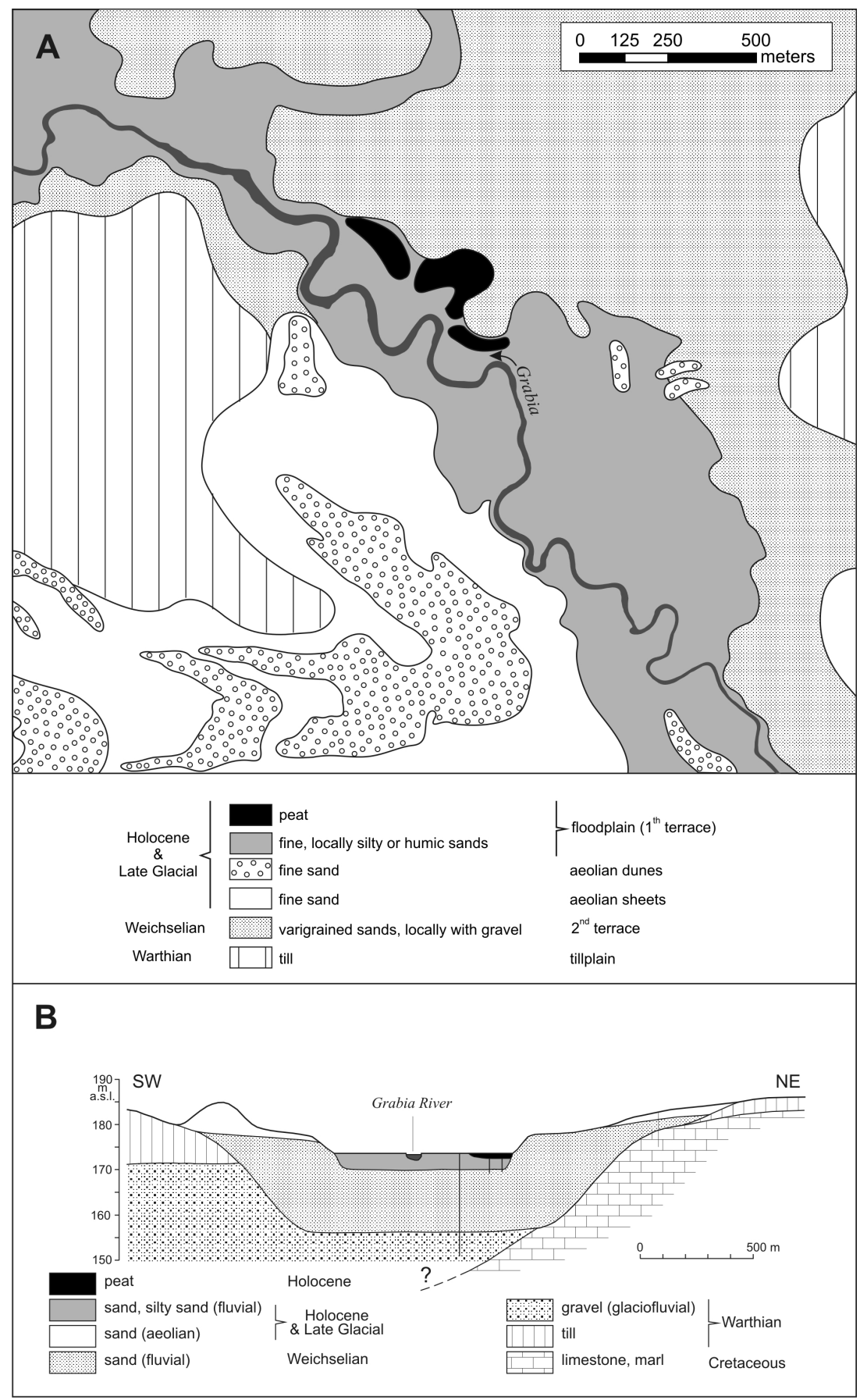

Fig. 2. Geological and geomorphological setting of study site based on Klatkowa (1987) and Central Hydrogeological Data Bank

A - Geological sketch of the study area; B - Schematic geological cross-section of the study area

within the Grabia valley. The upper terrace, consisting of sand, was formed during the Weichselian by the periglacial braided river (Fig. 2B). The lower terrace (the floodplain) is composed of silty sand, finegrained humic sand, or peat, as a result of channel and overbank deposition by the Late Glacial and Holocene meandering river. Aeolian sand covers the plains and terraces, as both aeolian sheets and dunes. The main phase of wind activity is dated as latest Weichselian; the secondary phase is of Holocene date.

This part of the Grabia River valley has not yet been the object of a multiproxy analysis, although the geology, geomorphology and hydrology of the valley have been studied (Maksymiuk, 1970; Klatkowa, 1987; Pelisiak \& Kamiński, 2004), and arti- 


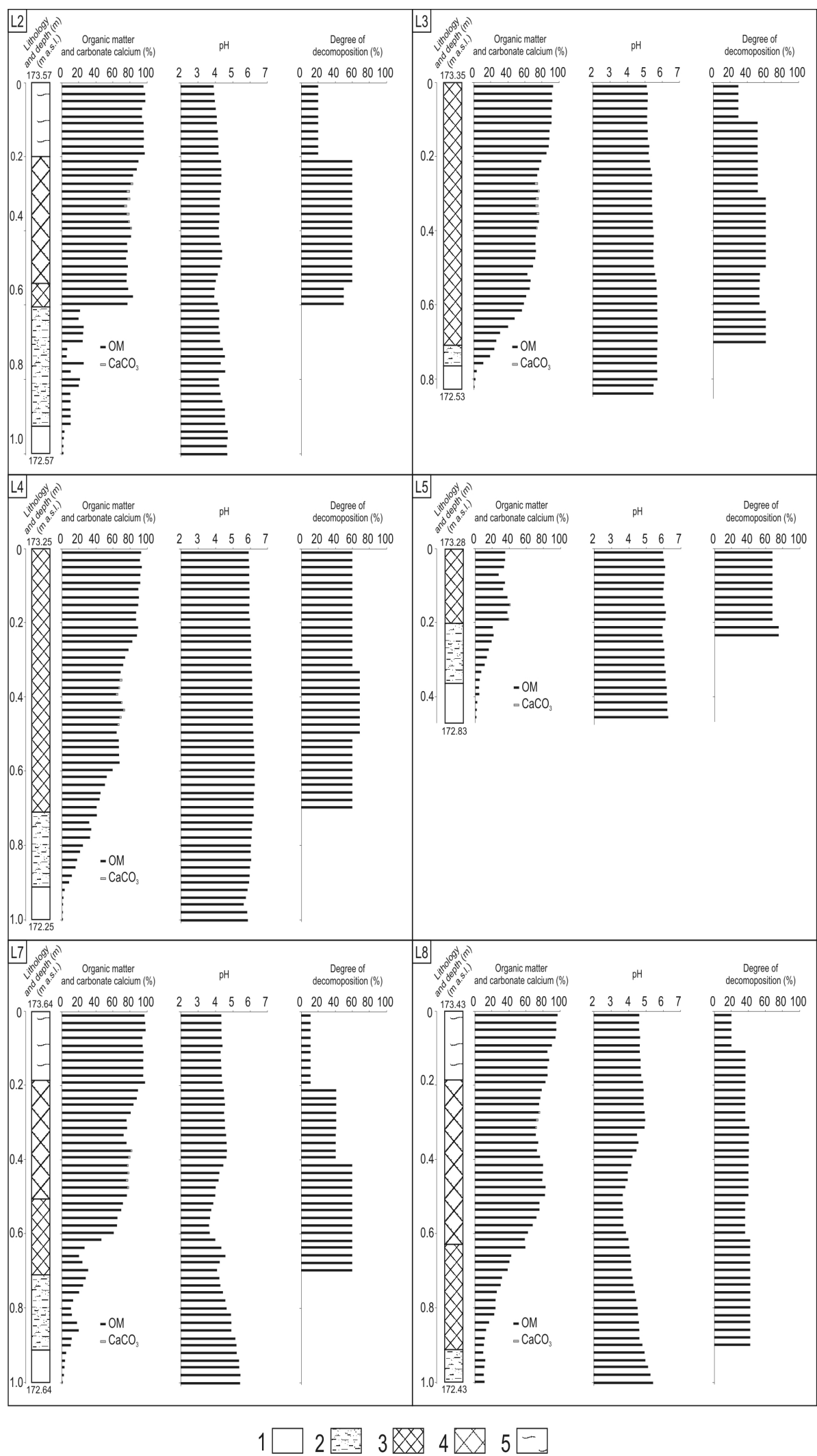

Fig. 3. Vertical distribution of organic matter, carbonate content, degree of decomposition and $\mathrm{pH}$ for cores from Ldzań mire

1 - mineral (sands) deposits, 2 - fine detrital gyttja with sand intercalations, $\mathbf{3}$ - sedge fen peat, 4 - sedge-moss peat, 5 - moss peat 
facts of human settlements have been the object of archaeological investigations (Pelisiak, 2004).

Today, the mire is dominated by an alder swamp. Sphagnum-moss communities occupy the northern part of the mire.

\subsection{Field work}

The geological and geomorphological studies concentrated on deposits and forms of the Holocene terrace. In particular, the spatial relationships between the peat and the clastic fluvial facies were investigated. The valley-floor morphology has been analysed using detailed topographic maps (scales 1:25,000 and 1:10,000), LiDAR-based Digital Elevation Model (DEM), and aerial photographs.

The thicknesses of the biogenic deposits were measured using a gauge auger and a manual Instorf corer (with a diameter of $5 \mathrm{~cm}$ and length of $50 \mathrm{~cm}$ ), up to $2 \mathrm{~m}$ set of extension rods. The drill holes (330 holes up to $2 \mathrm{~m}$ deep) were made in an approximately 5-metre irregular network (Fig. 1C). The coordinates of the drilling locations, set to a positional accuracy of 2 to $3 \mathrm{~m}$, were georeferenced using an Astech MobileMapper 10 GPS receiver. Because of dense vegetation (alder thickets and shrubs) on the mire, a Topcon Total Station (OS series) was used for detailed georeferencing of the six Instorf corers. The cores were made through the palaeochannels along the NE-SW and W-E oriented transects where the mire is the thickest (Fig. 1C). The depositional succession identified in detail from the core data consists of fluvial sands, gyttja and various types of peat (Fig. 3). The lowermost sediments in the palaeochannel are sands. Above, at the level of $c$. 173-174 $\mathrm{m}$ a.s.l., gyttja was re-
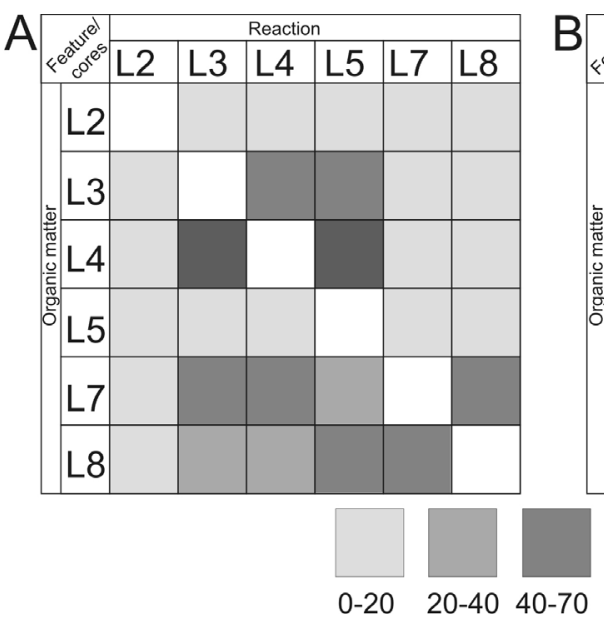
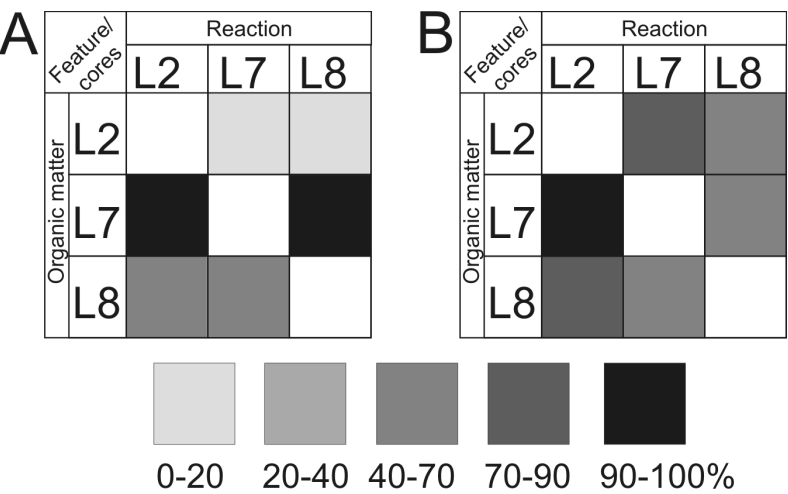

Fig. 4. Index of similarity structures of organic matter and $\mathrm{pH}$

A - Moss peat; B - Sedge-moss peat

corded with fine-grained sand intercalations (Fig. 3). Peat occurs from c. 0.5 to $0.8 \mathrm{~m}$ upwards. An organic succession from these sites was chosen for detailed laboratory analysis.

\subsection{Geochemical analysis}

Geochemical analysis was carried out on 266 samples taken from six cores every $2 \mathrm{~cm}$. Ash content and organic matter $(\mathrm{OM})$ and $\mathrm{pH}$ (in distilled $\mathrm{H}_{2} \mathrm{O}$ ) were determined by the standard methods used in chemical analysis of organogenic deposits (Myślińska, 2001; Tobolski, 2005a). The measurement of ash content in the biogenic deposits was performed in the exactly same way as the routine loss designation during the roasting process. After charring the sample under examination and subsequently roasting it at a temperature of $550{ }^{\circ} \mathrm{C}$, the percentage content of ash in dry matter (dried at a temperature of $105^{\circ} \mathrm{C}$ ) was taken as the raw ash content. The amount of carbonates present (expressed

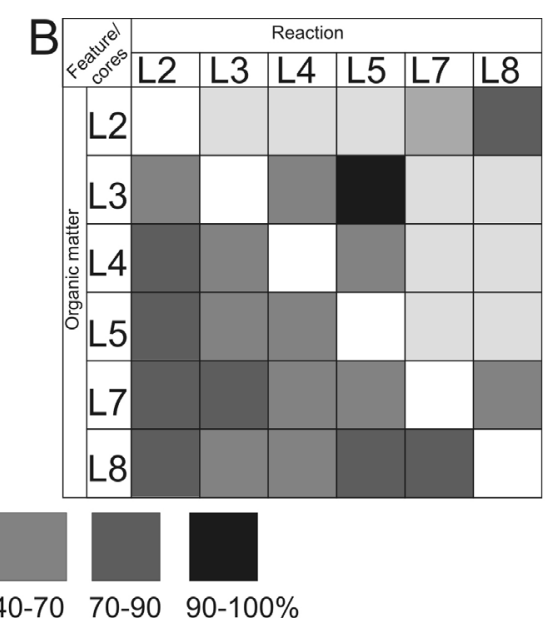

Fig. 5. Index of similarity structures of organic matter and $\mathrm{pH}$ A - Sedge fen peat; B - Fine detrital gyttja 
in $\mathrm{CaCO}_{3}$ ) was determined by the volumetric method, using the Scheibler apparatus (Rühle, 1973; Kaufhold, 2007; Woszczyk \& Szczepaniak, 2008). Additionally, the degree of decomposition $(\mathrm{H})$ by the method of von Post was determined as in Tobolski (2000). The biogenic deposits, mainly peat, were divided into groups depending on the OM of the peat (Okruszko, 1994) and the pH (Okruszko, 1991). The results are summarised in Figure 3.

To compare of the chemical composition of different types of biogenic sediments, the similarity index of structures $\left(\mathrm{w}_{\mathrm{p}}\right)$ was used (Dobrowolska, 2006) (Figs. 4, 5). This index was calculated as:

$$
\mathrm{w}_{\mathrm{p}}=\sum_{i=1}^{k} \min \left(\mathrm{w}_{1 i}, \mathrm{w}_{2 i}\right)
$$

where the $w_{1 i}$ are the indicators of the structure of the first population and the $w_{2 i}$ - are the indicators of the structure of the second population. The use of this method depends on the presence of clusters with the same shape and with roughly the same number of observations. The values of this similarity index are expressed as a percentage. The greater the incidence of the $100 \%$ value of this ratio, the greater the similarity of the structures. An index value equal to $100 \%$ indicates that the structures are identical. This indicator may be applied to data grouping, both due the trait measurable or by unmeasurable. This is the first time this indicator has been used in the assessment of variability of the depositional environment in peatlands.

\subsection{Geostatistical modelling}

The geostatistical modelling was performed separately for the two subsurface data sets. Firstly, on the basis of all data, the thickness and topography of the lower surface of the organic deposits (including peats and underlying gyttja) were modelled. Then the geochemical analysis data that were obtained from the six cores sampled every $2 \mathrm{~cm}$ were used to model spatial variability of the OM and $\mathrm{pH}$. ArcGIS 10 commercial software (ESRI, Redlands, CA, USA) supported by SAGA GIS (available at http:/ / www. saga-gis.org/) and SGEMS (Remy et al., 2009) open source software was employed here.

The input data used for geostatistical modelling were collected in the data base to provide the
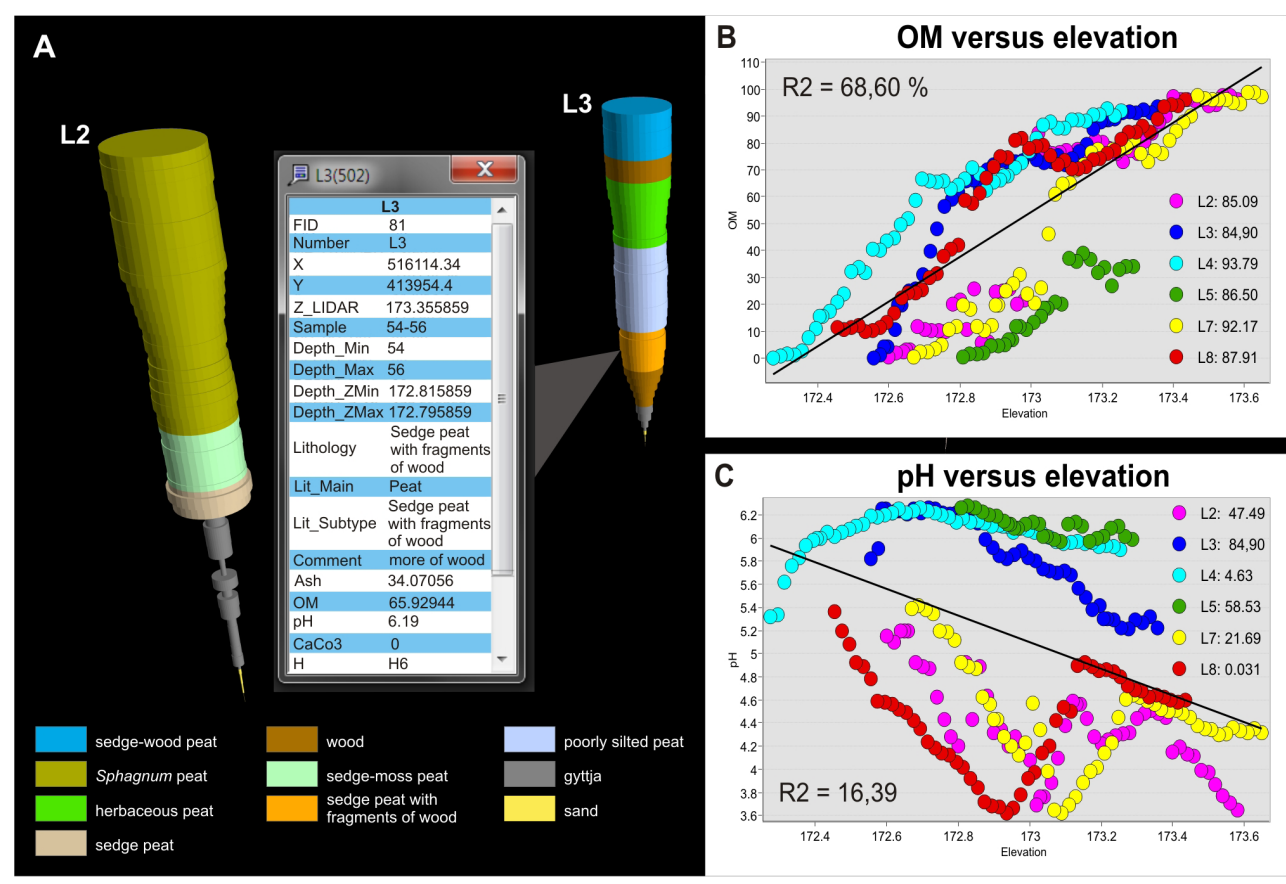

Fig. 6. Exploratory spatial data analysis (ESDA)

A - An example of visual exploration of input core data focused on spatial information on the vertical position of drilled sediments and their geochemical variables. The three-dimensional sedimentary logs have different radius according to OM. The pop-up window shows the details collected in the data base and related to the interactively selected layer in the sedimentary log; B - Scatter plot illustrating the positive linear trend related to vertical distribution of OM for all input core data. Note the list of the determination indices $\mathrm{R}^{2}$ calculated for each core; C - Scatter plot showing different elevation-pH dependences for all input core data and for each core. These dependencies are also described by the determination indices $\mathrm{R}^{2}$ 
$A_{\gamma \cdot 10^{-3}}$ Thickness of the organic deposits

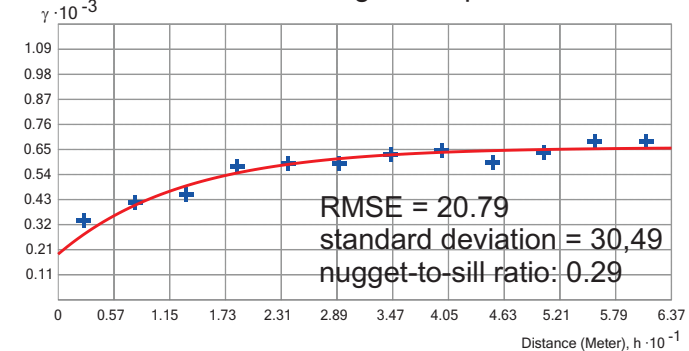

C

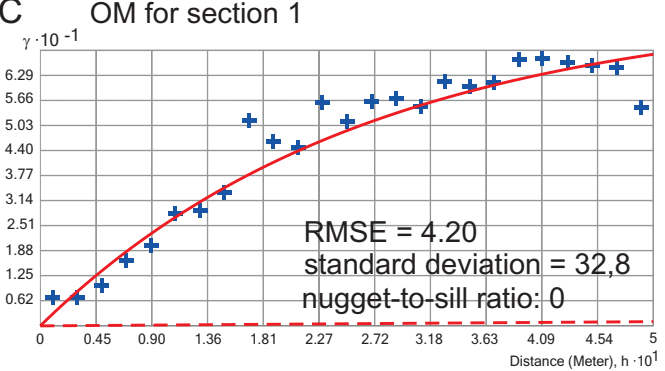

E

OM for all core data: vertical

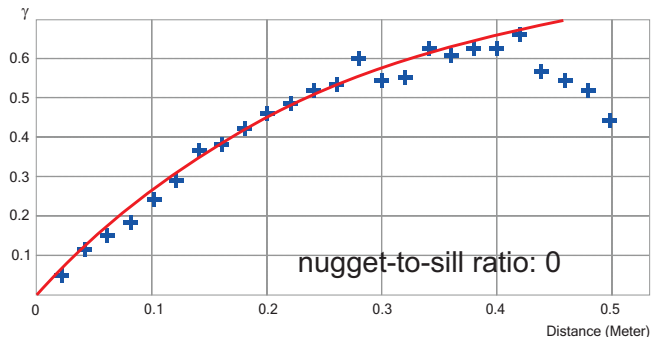

G

OM for all core data: horizonta

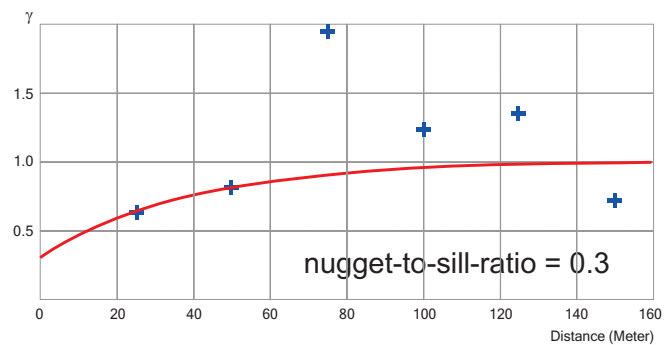

\section{B Bottom surface of the organic deposits}

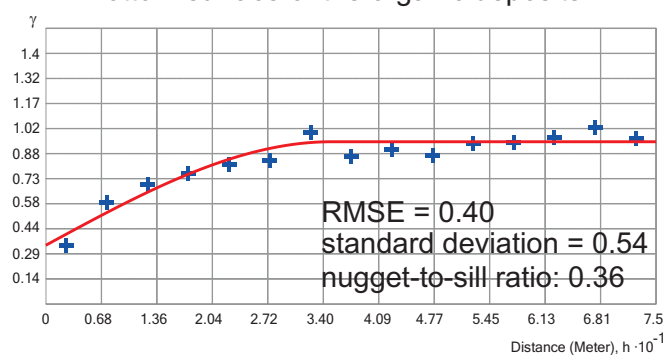

D $\mathrm{pH}$ for section 1

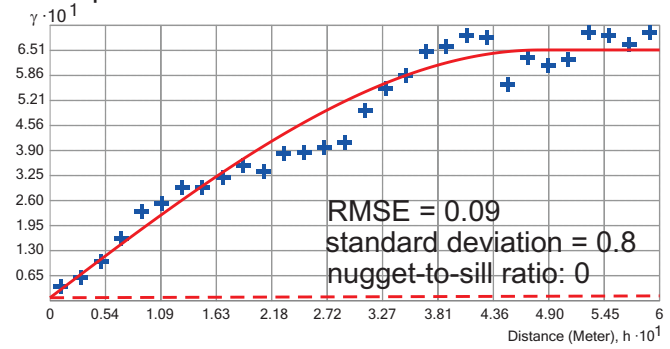

$\mathrm{F}$

$\mathrm{pH}$ for all core data: vertical

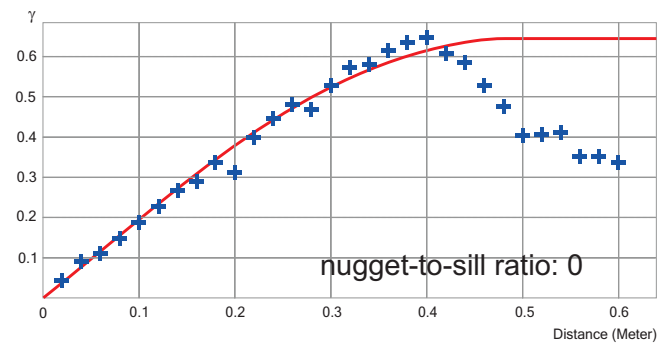

$\mathrm{H} \quad \mathrm{pH}$ for all core data: horizonthal

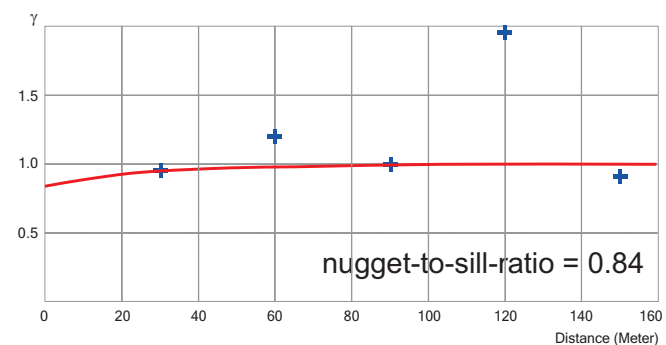

Fig. 7. Experimental semivariograms (blue markers) and corresponding fitted models (red lines) for the thickness of organic deposits and topography of their bottom surface $(\mathbf{A}, \mathbf{B})$, the $\mathrm{OM}$ and $\mathrm{pH}$ along the depth-distance section 1 (C, D) and for the $\mathrm{OM}$ and $\mathrm{pH}$ related to all core data (E-H). Note that the last semivariograms are calculated separately for vertical and horizontal directions. For additional explanation, see text

spatial information on the vertical position of the bottom and top of the drilled sediments. Moreover, each organic stratum was divided into 2-cm-thick subunits, for which geochemical data were also collected.

A visual exploration of the input data was carried out, and the descriptive statistics were calculated, in the framework of the exploratory spatial data analysis (ESDA) (Fig. 6). This first stage of geostatistical modelling is focused on the identification of outliers, the analysis of the normality of the statis- tical distribution, and trend determination. This is because of the general assumption in geostatistics that random function must be stationary and, thus, that the input data should be normally distributed and detrended (Isaaks \& Srivastava, 1989; Deutsch \& Journel, 1992). For this purpose, a normal-score transformation was applied to symmetrise the input data histograms. Moreover, for some data, the detrending was performed by linear regression, with a determination index $\mathrm{R}^{2}$ greater than $60 \%$ (Fig. 6B). 
The analysis and modelling of the spatial autocorrelation structure related to the input data was explored using empirical semivariograms (Isaaks \& Srivastava, 1989; Pyrcz \& Deutsch, 2014) (Fig. 7). These show the dissimilarity between the input data separated by a distance $\mathrm{h}$ (lag size), and thus, according to Tobler's law of geography (Miller, 2004), they are an effective tool for evaluating the dynamics, range and anisotropy of the spatial variability of the data. The empirical semivariograms were modelled using a weighted-least squares fitting method, implemented in the Geostatistical Analyst extension to ArcGIS (Krivorushko, 2011). This was applied not only to the thickness and topography of the bottom surface of the organic deposits analysed in the $X-Y$ coordinate system (Fig. 7A-B), but also to the geochemical variables which were modelled along elevation-distance sections (Fig. 7C-D). In the latter case, the vertical semivariograms were calculated and modelled separately for each section. Additionally, for 3D geostatistical modelling of the geochemical variables, the vertical and horizontal semivariograms were calculated separately and modelled for all input core data, in line with Pyrcz \& Deutsch (2014) (Fig. 7 E-H). The modelling of these semivariograms was performed using eye-fitting tools implemented in the SGEMS software (Remy et al., 2009), although using the previously defined models fitted for vertical semivariogram related to the elevation-distance section 1. Finally, the models defined for the vertical and horizontal semivariograms were combined into a single 3D model.

The resultant semivariogram models were analysed in detail to determine the nugget-to-sill-ratio. This parameter indicates a degree of spatial continuity or heterogeneity of the autocorrelation structure that arises from random components within the total spatial variability (Robertson et al., 1993). Low values of the parameter show a strong spatial autocorrelation; high values, in turn, indicate a weak spatial autocorrelation or none at all.

All input variables were interpolated at unsampled locations using ordinary and simple kriging methods. Moreover, the sequential Gaussian simulation was performed for modelling of the spatial distribution and the uncertainty of the geochemical variables. For each modelled variable we obtained multiple equiprobable realisations of the spatial distribution.

The spatial resolution of the resultant 2D and 3D grid models was optimised using the point pattern analysis method (Hengl, 2006). For example, the mean nearest distance between all subsurface data analysed in the $\mathrm{X}-\mathrm{Y}$ coordinate system equalled 5.8 $\mathrm{m}$, and so the thickness (Fig. 8A) and topography of the bottom surface of the organic deposits (Fig. 8B) were modelled with a spatial resolution of $1 \times 1 \mathrm{~m}$, which is less than the critical resolution of $2.9 \times 2.9$ $\mathrm{m}$. For the 3D-grid models in turn, a vertical resolution of $0.01 \times 0.01 \mathrm{~m}$ and a horizontal resolution of $5 \times 5 \mathrm{~m}$ were determined. Moreover, the same vertical resolution was specified for modelling of the geochemical variables along the elevation-distance sections.

The optimisation of the kriging methods for interpolation was performed using trial and error tests, supported by evaluation of the semivariogram models and the resulting grid models against expert knowledge. The cross-validation allowed the accuracy and bias of the predictions to be assessed. The root-mean-square error (RMSE) and the regression coefficient for the measured vs predicted variables were important here (Fig. 7A-D).

The input data, and some of the resultant grid models, were additionally geoprocessed at different stages of geostatistical modelling. All subsurface input data were recalibrated from the original unreferenced depth domain to the elevation domain using the LiDAR-based DEM. Moreover, DEM was used to delineate of the external border of the resulting grid models, where the mire is adjacent to the high topographic scarp on the east. In addition, the model of the bottom surface of the organic deposits was merged with DEM, to obtain the palaeotopographic model prior to the mire's development.

\section{Results}

The mire is located on the outer part of floodplain. It fills an erosional incision in the upper terrace, which is semicircular in plan (Figs. 1B, 2A). The mire is nearly isometric $(130 \times 140 \mathrm{~m})$. Its flat surface is at a level of $173.5 \mathrm{~m}$ a.s.l. The depression studied here is isolated from the Grabia River channel by a slight (0.5 m high) elevation containing sandy deposits of natural levees and/or crevasse splays. In the northern marginal part, the peat is covered by a thin deluvial deposit (sand) washed out from the slope of the higher terrace.

The geological and geomorphological situation suggests that the mire developed in an oxbow of the Grabia River. The ancient channel was characterised by sinuosity in the range of $1.8<\sin <2.1$, and the average radius of palaeomeanders is $r_{m}=63$ $\mathrm{m}$ (these parameters are $\sin =1.7, \mathrm{r}_{\mathrm{m}}=44 \mathrm{~m}$ for the present-day Grabia River). The studied palaeomeander was most likely formed during the Younger Dryas or even in Allerød, which is shown by the 

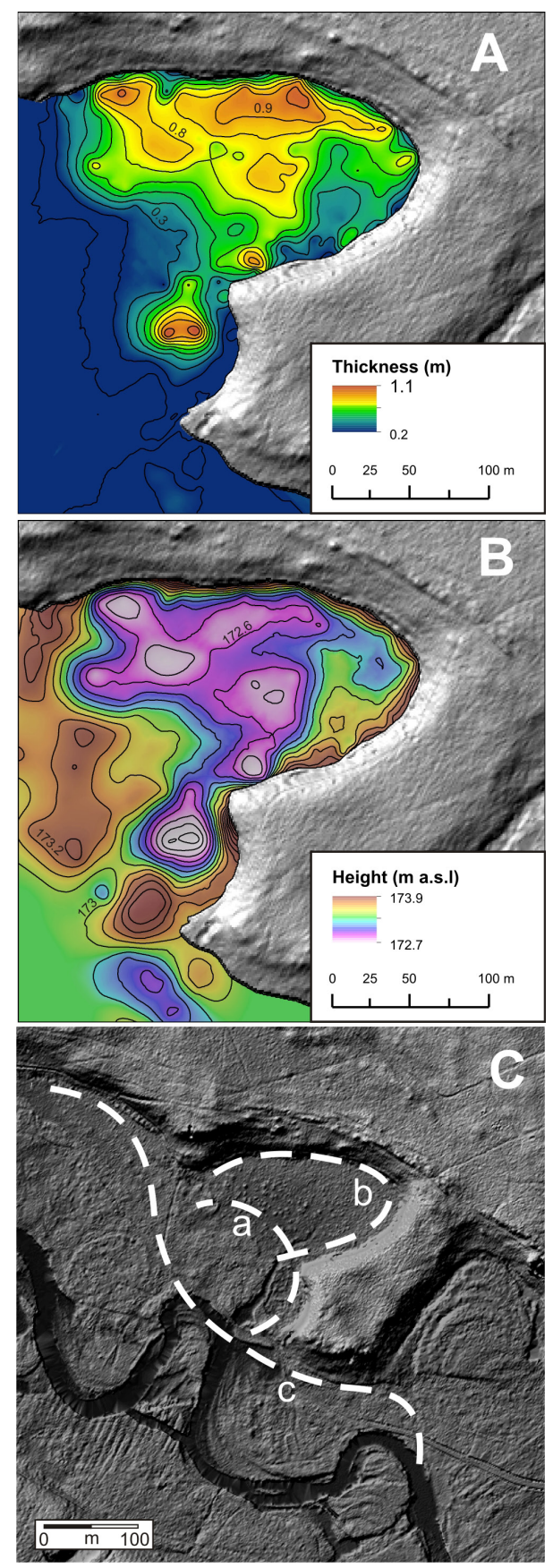

Fig. 8. A - Maps of thickness of organic deposits; B - Topography of their bottom surface. In both cases, note contour lines with a $0.1 \mathrm{~m}$-interval; C - Successive phases of the Grabia River channel location: $a, b$ pre-avulsion phases, c - post-avulsion

fact that the silts infilling analogous palaeomeander in the study area have been dated at $11,820 \pm 210$ BP (Pelisiak \& Kamiński, 2004).

A spatial variability of peat thickness is shown in Figure 8A. In the central part of the palaeomeander, the organic deposits attain their greatest thickness of up to $1.0 \mathrm{~m}$. This thickness is maintained for almost the entire length of the palaeomeander; the greatest depths are located in the eastern and western parts of this structure (Fig. 8). The northern part of the mire is characterised by homogeneity of the organic sediments; Sphagnum-moss peats are located here. To the south, towards the river, peats are represented by sedge-moss peats and sedge peats with wood fragments (alders). The main series of biogenic sediments in most of the cores are sedge peats. Their thickness ranges from $0.24 \mathrm{~m}$ in the western part of the fen (core L5) up to $0.70 \mathrm{~m}$ in the middle part (cores L3 and L4). This sedge peat overlies fine detrital gyttja with a thickness of 0.06 (L3 core) to $0.20 \mathrm{~m}$ (cores L4 and L7). The gyttja is occasionally intercalated by fine-grained fluvial sands, which in turn are located in the lowermost part of the mire. Such sediment sequence indicates that this is mainly the result of changes in hydrology and the transformation of the oxbow lake into a mire. Initially, the oxbow was a reservoir with weak currents supplied from the nearby river channel. With time, the river's impact decreased because both environments (the alluvial channel and oxbow lake) became increasingly separated by channel migration or aggradation of natural levees. Moreover, it is most probable that the river discharges successively decreased during the Holocene (compare Turkowska 1988, 2006).

\subsection{Results of geochemical analysis}

Detailed diagrams of each physical and geochemical parameter are presented in Figure 3. Additionally, $\mathrm{OM}$ and $\mathrm{pH}$ records are plotted vs elevation, to allow for a correlation between geochemical values in each section of the mire (Fig. 6 B-C).

The content of organic matter in fine detrital gyttja ranges from $4.35 \%$ in samples taken from the western part of the mire to $40.4 \%$ in the central part. The average content of organic matter is lowest at core L5 (10.7\%) and core L8 (11\%), and is two times lower than these features in the central and northern parts of the mire (L2 and L4 cores). The accumulation of fine detrital gyttja occurred in two types of environment (following classification by Okruszko, 1991): highly acidic (cores L2 and L7) and moderately acidic (cores L3, L4, L5 and L8). The content of organic matter in sedge peat ranges from $10 \%-20 \%$, in the samples taken from marginal portions of the mire, to $93 \%$ in the middle part. The average level of features is lowest at cores L8 (29\%) and L5 (32\%), which is half the value of these parameters in the L3 and L4 profiles (72\%). The coefficient of variation of the organic matter for sedge peat is not high, and ranges from $19 \%-23 \%$. The eastern part of the mire 
is an exception, because the coefficient of variation there is twice as high, exceeding $40 \%$. Deposition of autochthonous organic matter, which built up the sedge peat in the eastern part of the mire, occurred in an acidic environment. Peat reaction values are in the range from 3.6 to 4.7 following Okruszko's classification (1991), these are in the strongly acid category. In the central and western part of the fen, the sediment reaction is moderately acidic (range 5.2 to 6.2). The increased $\mathrm{pH}$ of sediments in those parts of the mire correlates with the presence of calcium carbonate. The maximum share of calcium carbonate is only $1.7 \%$.

The deposit-forming process that forms sedgemoss peat is documented only in the eastern part of the mire. This sediment is characterised by a high value of the coefficient of variation (from $56 \%$ in core L2 to $65 \%$ in core L8), very highly acidic or highly acidic reaction ( $\mathrm{pH}$ is between 3.62 and 4.92) and moderate values of the degree of decomposition of organic matter ( $\mathrm{H}$ between $45 \%$ and $60 \%$ ). The content of organic matter in the sedge-moss peat ranges from $61 \%-90 \%$. The average content of the features is similar in all the cores $(74 \%-79 \%)$. There is no correlation between reaction and calcium-carbonate content. The peat in the upper layers of the eastern part of the mire has changed, having been built up by a moss bog. The plant structure in this peat is distinct, but the residue after squeezing is not pulp-like (H ranges from 10\%-20\%). The content of organic matter in the moss peat ranges from $81.4 \%$ in samples taken from core L8 to $98.8 \%$ in core L7. The average content of organic matter is lowest in core L8 $(88.6 \%)$, and is $9 \%$ lower than these features in cores L2 and L7. The ash, reaction, and degree of decomposition of the peat sediments are consistent with the general properties of peat in Poland (Table 1). The highest average of the similarity index of structures (above 70\%) was found between the moss and sedge-moss peat in all fen profiles. A very high sim- ilarity was documented in the organic matter and $\mathrm{pH}$ (Fig. 4). Moderately similar values of organic matter were shown by a fine-detrital gyttja over the entire surface of the mire (Fig. 5). The high similarity of the $\mathrm{pH}$ of the fine-detrital gyttja (over 70\%) was documented only in the central and western parts of the mire (cores L3, L4 and L5). Moderately similar values of $\mathrm{pH}$ were seen in the eastern part of the fen, where the average (over cores L2, L7, and L8) of similarity index of structures was $\mathrm{w}_{\mathrm{p}}=47 \%$.

\subsection{Results of geostatistical modelling}

The empirical semivariograms displayed in Figure 7 show the different dynamics and ranges of spatial variability inferred from the subsurface data. Moderate nugget variance was estimated for the thickness and the bottom surface of the organic deposits (Fig. 7A-B). The nugget-to-sill ratios equal 0.29 and 0.36 , respectively. This can be explained by the higher variability within distances smaller than the shortest horizontal sampling interval of the subsurface input data. Moreover, some influence from the small-scale erosion-based anisotropy typical of fluvial environments can be expected here (Watts et al., 2010; Zapata-Rios et al., 2012). In this context, it is important to note that more estimation errors related to the deeper sampled input data were obtained in the cross validation test.

It is noteworthy to discuss the semivariograms of the geochemical variables. These show the vertical variability, which is continuous up to a few tens of centimetres and did not reveal the occurrence of the nugget variation (semivariograms start from zero) (Fig. 7C-F). The spherical and exponential models were fitted to the vertical semivariograms for $\mathrm{OM}$ and $\mathrm{pH}$, respectively; they thus show the more or less constant dynamics of the spatial variability. Note that, in the vertical semivariogram of

Table 1. Important properties of selected biogenic sediments in Poland

\begin{tabular}{lcccc}
\multirow{2}{*}{ Type of sediment } & \multicolumn{3}{c}{ Ranges } & References \\
\cline { 2 - 4 } Fine detrital gyttja & Mineral matter (\%) & $\mathrm{pH}$ & Degree of decomposition (\%) & Dobrzański \& Zawadzki (1995) \\
& $53-68$ & $6.6-7.5$ & - & Kozakiewicz (1962) \\
Sedge fen peat & $10-26$ & $5.0-6.4$ & $25-55$ & Maksimow (1965) \\
& $7-15$ & $4.3-6.0$ & $30-40$ & Oświt et al. (1976) \\
& $10-20$ & $6.0-7.0$ & $30-50$ & Frankiewicz (1980) \\
Sedge-moss peat & $8-14$ & $6.2-7.5$ & $25-35$ & Oświt et al. (1980) \\
& $10-25$ & $5.2-7.2$ & $25-55$ & Maksimow (1965) \\
\multirow{2}{*}{ Moss peat } & $6.5-10$ & $5.0-6.0$ & 30 & Oświt et al. (1976) \\
& $3.6-13$ & $4.0-6.8$ & $10-35$ & Frankiewicz (1980) \\
& $6.0-12$ & $6.5-7.0$ & $25-30$ & Oświt et al. (1976) \\
\hline
\end{tabular}


the $\mathrm{pH}$ for section 1 (Fig. 7D), an additional smallscale spatial structure can be defined by the partial sill of c. $0.39 \mathrm{~m}^{2}$ and the partial range of $c .0 .21 \mathrm{~m}$. This structure corresponds well to the second-order short-distance variability, which can be recognised in the vertical distribution of the $\mathrm{pH}$ for the L2 core data between 173.3 and $172.8 \mathrm{~m}$ a.s.l. (Fig. $6 \mathrm{C})$. Other core data in section 1 show the vertical variability, which is more closely related to the total sill of $0.48 \mathrm{~m}^{2}$ and to the total range of $0.64 \mathrm{~m}$ in the semivariogram. Moreover, the vertical semivariogram of the $\mathrm{pH}$ prepared for all core data is more continuous. For this reason, the small scale spatial structure was ignored in the semivariogram model fitted for the cross 1 core data.

The horizontal variability of the geochemical parameters is not continuous with a moderate to high nugget effect. The nugget-to-sill ratios calculated for the $\mathrm{OM}$ and $\mathrm{pH}$ equal 0.3 and 0.84 , respectively. Of course, the assumed and speculative semivariance models are based solely on the seven semivariance values calculated for the distance lags determined from the core data, which are very sparsely distributed in the horizontal directions. It should be noted that this sparseness of the core data may influence the unreliable and very strong nugget-like effect in horizontal semivariograms (Pyrcz \& Deutsch, 2014). For this purpose, semivariogram modelling can be supported by secondary data, conceptual models, and expert knowledge. In this work, the modelling of the horizontal semivariance was supported by a trend analysis of the vertical distributions of the $\mathrm{OM}$ and $\mathrm{pH}$. The scatter plot displayed in Figure $6 \mathrm{~B}$ shows the positive linear trends related to the $\mathrm{OM}$ distributions. A determination index $\mathrm{R}^{2}$, calculated for each core and separately for all core data, ranges from $68.60 \%$ to $93.79 \%$ and thus indicates a high to moderate elevation-OM dependence. On the basis of these trends, we assumed very strong horizontal anisotropy, with the range of $112.5 \mathrm{~m}$ determined from the modelling of the horizontal semivariogram. This horizontal range was then combined with the vertical semivariogram model to obtain the final 3D semivariogram model. The horizontal to vertical anisotropy ratio related to this final model is 140, and corresponds well to the typical ratio values for different sedimentary environments and in particular for estuarine and deltaic environments (Pyrcz \& Deutsch, 2014). In a similar way, the 3D semivariogram model was determined for the $\mathrm{pH}$, despite its weak dependence on elevation (Fig. 6C). The values of the determination index $\mathrm{R}^{2}$ range from $0.031 \%$ to $84.78 \%$. Such different elevation- $\mathrm{pH}$ dependencies for the individual cores arise from the small-scale linear distributions with different dynamics of variability rather than from a clear sparseness of the $\mathrm{pH}$ versus elevation. Moreover, the small-scale linear distributions show similar dynamics between neighbour core data at similar elevation intervals. For the $\mathrm{pH}$ spatial variability, we assumed a strong horizontal anisotropy with the range of $85 \mathrm{~m}$ determined from the modelling the horizontal semivariogram, and thus the horizontal to vertical anisotropy ratio for the final 3D semivariogram model is 177 .

The 3D semivariogram models obtained for the $\mathrm{OM}$ and $\mathrm{pH}$ were used for weighted-average interpolation and simulation based on the simple kriging algorithm. On account of the strong horizontal anisotropy, samples from at least two neighbour cores were always proportionally weighted to estimate or simulate new values. The resultant $2 \mathrm{D}$-grid models performed along elevation-distance sections are summarised in Figure 9. Additionally, the resultant $3 \mathrm{D}$-grid model of the $\mathrm{OM}$ and $\mathrm{pH}$ are displayed, with some transparent voxels, in Figure 10.

\section{Discussion}

The spatial distribution model of the physicochemical properties studied indicates the influence of varied processes during existence of the mire. The various horizontal and vertical distributions of these parameters show that the Ldzań mire was controlled chiefly by different water influxes, differing in type and abundance of water.

In the lower part of the mire succession, $\mathrm{pH}$ values vary and are characteristic of fens ( $\mathrm{pH}$ 5-6.5; see cores L2, L7, and L8; Fig. 3). The upper part of the mire succession is more acidic $(\mathrm{pH}$ in the range 4.5-5), but the uppermost part of the mire is characterised by the greatest acidity of the peat $(\mathrm{pH}$ below 4.5), as is typical of transitional peatlands (Kozakiewicz, 1962; Maksimow, 1965; Okruszko, 1991; Domińczak \& Okupny, 2010; Rydelek, 2011; Okupny et al., 2013). Adjacent to cores L2, L7, and L8, located in the deepest part of palaeomeander (Fig. 9) next to the escarpment, low $\mathrm{pH}$ values occur and are characteristic of strongly acidic peat (Fig. 3). The lowest values of $\mathrm{pH}$ (acid conditions) occur in the central part of palaeomeander (near the core L2). Towards the SW (and the river), the acidity decreases; at the edge of the mire (adjacent to the core L5), the $\mathrm{pH}$ exceeds 6, and is typical of fens. Such vertical and horizontal lens-shaped decreasing pattern of $\mathrm{pH}$ values, illustrated well in the 3D-grid model (Fig. 10B), may suggest diversified water supply of the Ldzań mire. The lower part of the organic sequence in the central and eastern part 

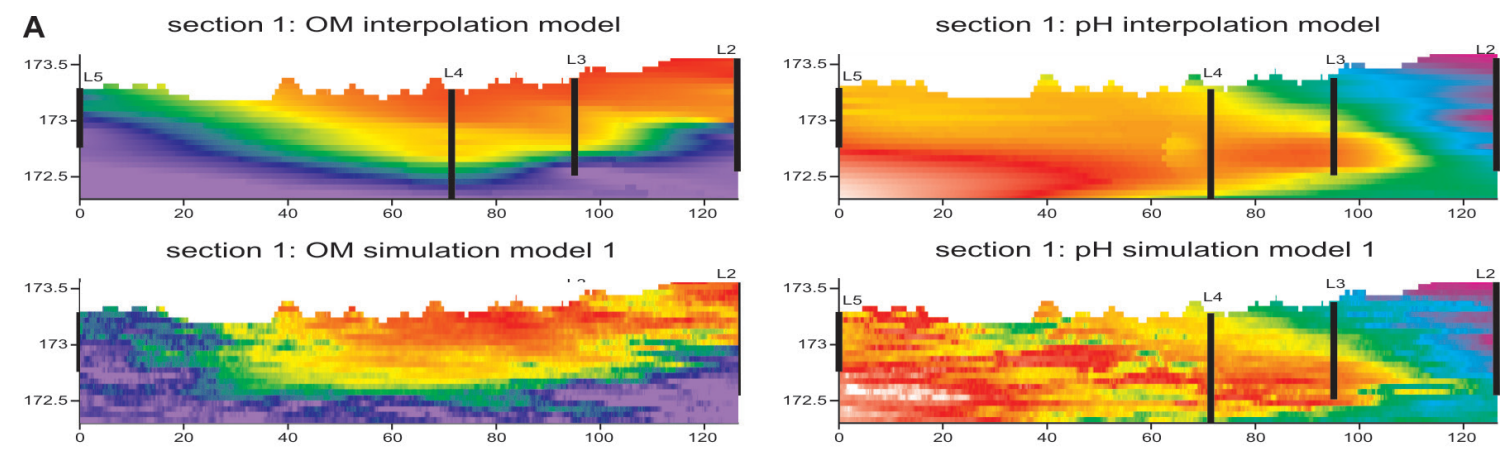

section 1: OM simulation model 2

section 1: $\mathrm{pH}$ simulation model 2
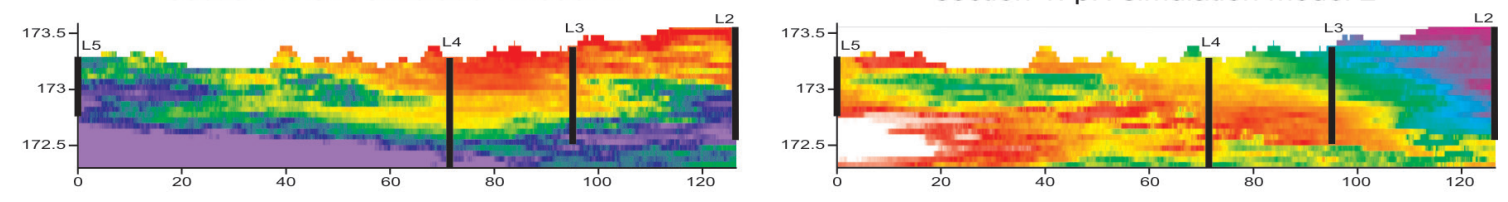

B Section 2: OM interpolation model 1
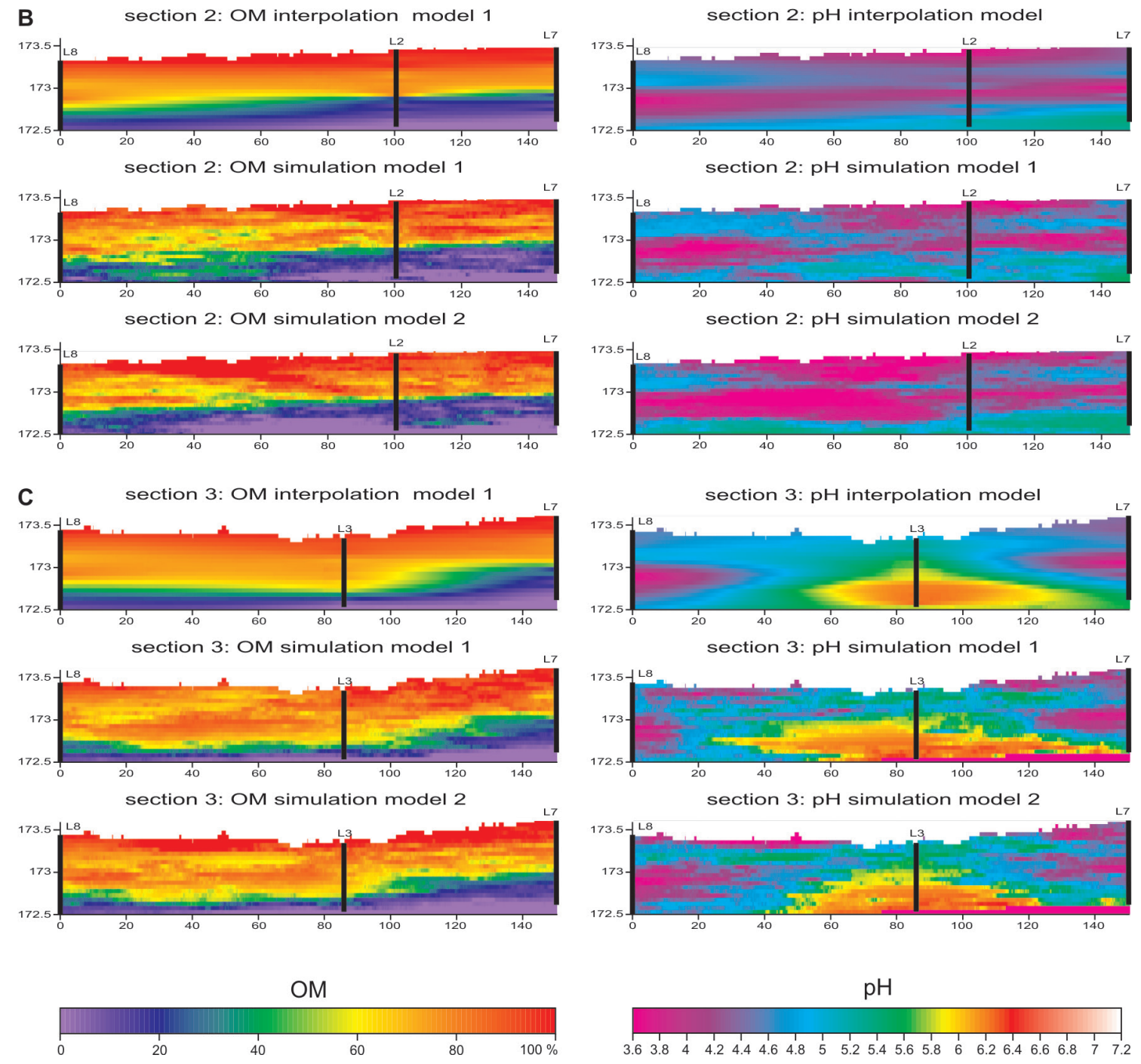

$\mathrm{pH}$

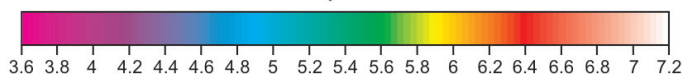

Fig. 9. 2D-grid models performed along elevation-distance sections showing spatial distribution of OM and $\mathrm{pH}$. For each section three models are illustrated; one resulting from the simple kriging estimation, and two others obtained from the sequential Gaussian simulation 
of mire near the escarpment (Fig. 9A,C) probably is fed mainly by groundwater, richer in mineral components. This second-order, short-distance variability was recognised in the vertical distribution of the $\mathrm{pH}$ for data from cores L2, L7, and L8 between $c$. 173.3 and $172.9 \mathrm{~m}$ a.s.l. (Fig. 6C). Such type of water supply resulted in a slight neutralisation of the acid products of plant decomposition. This is also confirmed by the high values of the similarity index of structures (Fig. 5). The depositional environment and complex water economy are reflected well by the diversity in the similarity index of structures, reacting to the supply of mineral or rainwater in different parts of the mire. The hydrogeological conditions, the changes in fertility and the phase of increased mechanical denudation all determine the peat-forming accumulation environment in valley mires (Okruszko, 1979; Tobolski, 2005b; Wójcicki, 2013). However, the predominance of coniferous forests in the catchment may also exert an influence on these $\mathrm{pH}$ values. The acidification favoured invasion by plant communities typical of more oligotrophic mires (such as Sphagnum mosses). The absence of calcium carbonate in the sediments, except for the uppermost $0.2-0.4 \mathrm{~m}$ where $\mathrm{CaCO}_{3}$ content did not exceed $2 \%$ (Fig. 3), was conducive to this situation. The lack of carbonates contributed to the increase in the content of organic compounds in the form of free fatty acids, which in turn caused a decrease in $\mathrm{pH}$ values and in the fertility of the mire (Ilnicki, 2002).

In turn, parts of the organic sequence in the mire closer to the river and adjacent to cores such as L3, L4, and L5 (with values of the similarity index of structure often exceeding $40 \%$ ), are dominated by sedge peat and have the highest values of $\mathrm{pH}$ (Fig. 9A). The sedge peat may indicate the presence of surface-water flow (Forysiak et al., 2012) as a result of seasonal flooding of the Ldzan mire. This influence of the Grabia River and of the supply of groundwater in this part of the mire led to neutralisation of the $\mathrm{pH}$ in the mire. Water flow provides a constant supply of nutrients, and determines the content of oxygen in the biogenic accumulation environments in peatlands. This results in acid elution from the decomposition of organic matter. In this way, the flow of water affects not only the vegetation of peat bogs, but also the direction of the bio-

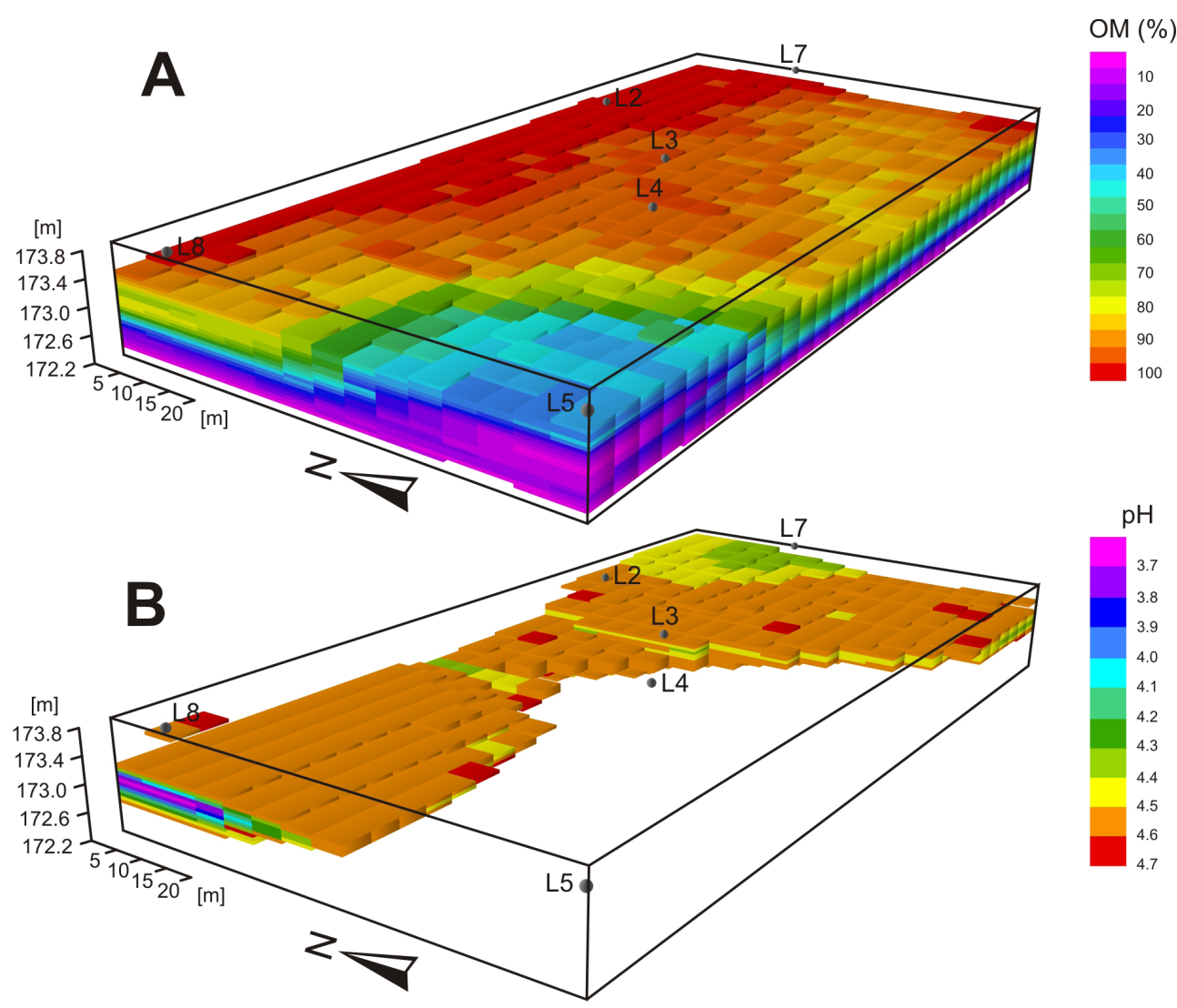

Fig. 10.3D-grid models resulting from simple kriging estimation

A - OM; B - pH. Note that the voxels with the $\mathrm{pH}$ values greater than 4.7 are not displayed to show the fan-like geometry of the organic deposits having low $\mathrm{pH}$. The locations of the Instorf corers provide a spatial reference of both grid models 
chemical processes occurring in it (Okruszko, 1964; Oświt et al., 1980).

The sedge peats, sometimes with fragments of wood, not only formed in the periodic flooding, but were also controlled by groundwater drainage from the valley. Some waterlogged conditions in the mire were connected with the presence of groundwater as a result of the location within the zone of groundwater discharge at the foot of the valley side. Thus, the presence of shallow groundwater allows the formation of peat in periods of low water level in the river (Okruszko, 1976; Dembek \& Oświt, 1992; Żurek, 2006). In the central part of the palaeomeander, the sedge peat is covered by Sphagnum-moss peat. This may indicate a reduction of the flood and the presence of strong waterlogging and shallow groundwater (Forysiak et al., 2012).

The diversified water supply of the Ldzan mire is confirmed by the variable contents of mineral matter (MM) in the sediments. $\mathrm{MM}$ is a recognised as the inverse of the OM content, and provides for the distribution of allochthonous components (Myślińska, 1999; Wójcicki, 2007). The MM content in the southwestern part of mire located in the immediate proximity of the river (Figs. 3, 9, near core L5) is significantly higher (over $60 \%$ ) than in other parts, or even predominates. Moreover, the 3D-grid model of OM distribution shows that MM creates a fan-like structure with an apex located in the mire, and becomes wider towards the river (Fig. 10A adjacent to core L5; see also Fig. 9A - especially simulated models). In the western part of the mire, three types of peat occurred (following classification by Okruszko, 1994); heavily silted, poorly silted, and unsilted. This is countered by the increase in $\mathrm{OM}$, which takes values over $98 \%$ towards the central part of the palaeomeander, where only poorly silted and unsilted peat occurred. Also, sudden and relatively significant changes in the abundance of MM were observed in the middle part of the organic sequence adjacent to cores L2, L7, and L8 (Fig. 9). These variations in MM content are also characteristic in the vertical distribution of this feature. In the lower parts of the organic sequence located in the central part of the palaeomeander, the abundance of MM is high. This indicates a greater supply of allochthonous deposits and MM by the river. The enrichment of clastic particles seems to be partly synchronous, and may reflect episodic or seasonal flood inflows. The fine texture of sand grains indicate that the sediment was supplied from the channel to the mire by suspension load. Suspension transport is mostly characteristic of flood stages. The decreasing amount of OM towards the margins of the mire may argue for the position that relatively short-term floods occurred at this time.

Our study of another mire in the Grabia River valley registered the presence of sand layers up to several centimetres thick intercalating with the peat intervals (Pawłowski et al., forthcoming). The analogous layers are missing in the Ldzań mire, which needs some discussion. In our opinion the studied peat succession fills the oxbow derived from channel avulsion. During a large flood the channel shifted towards the axial part of the valley and the palaeomeander was abandoned (Fig. 8C - phase b). As a rule, the newly formed channel is characterised by a lower sinuosity than the channel prior to avulsion (Van Gelder et al., 1994; Jones \& Harper, 1998; Smith \& Pearce, 2002). The Grabia River reacted in the same way (Fig. 8C - phase c). The relatively low supply of the mire by fluvial sand can be explained by post-avulsion river morphology. In a slightly sinuous channel the sand is transported downstream the valley - in axial direction, whereas in the case of sharply bended meander a lot of sediment is transported outside of the channel belt. Moreover, after avulsion the mire studied became located on the inner bank of the channel bend, i.e. in the zone where the overbank transport is minimal. The morphology of the higher terrace can be considered an additional factor. The mire studied lies in the most marginal part of floodplain, and it is protected from influence of flood waters by the terrace 'ramp' oriented transversely to the valley axis (Fig. 8).

The examination of the ash content has a large diagnostic significance, as it quite clearly indicates the relationships with particular types of peat or the degree of decomposition. The ash may result from the decomposition of vegetable matter or from allochthonous matter, delivered to the mire regardless of its natural development (Kwiatkowski, 1971; Frankiewicz, 1980). Raised peat is characterised by a low mineral content of up to a few percent, while fen peat contains more mineral matter, usually from 8 to $20 \%$ of peat dry matter (Tobolski, 2005a). In fen peat, peat with prevailing reed and wood has a larger ash content than does mossy or sedge peat. A larger quantity of ash is also determined by the degree of peat decomposition (Table 1). Raw ash is the residue after roasting and is associated with the presence of peat-forming plants; secondary ash is the result of the application of processes to mineral matter by water or wind on the mire (Maciak \& Liwski, 1996; Szajdak, 2002). Highly decomposed peat is characterised by higher ash contents than in analogous, less decomposed formations. The amount of raw ash ranges from $2 \%$ for peat built from particular plant matter with ombrogenic peat-forming 
properties, to $7.5 \%$ for peat built from communities of large sedges (Kwiatkowski, 1971). The average content of mineral matter in the different types of peat in Ldzań ranges from a few to several tens of percent (Fig. 3) and increases in the following order: moss, sedge-moss and sedge fen peat. These results are consistent with the physicochemical values of peats noted by Paivanen (1973) and Szymanowski (1993). The vertical variability of marked characteristics in Ldzan, with the exception of the impact of floods, seems to result from autogenic changes. These changes caused, among other effects, the succession and terrestrialisation of the water body; they are typical of the water conditions of peat-creating habitats on fens (Okruszko, 1976).

The high ash content may indicate anthropogenic impact (Żurek, 1993). However, the relatively low ash content in the Ldzań deposits (below 18\%) does not confirm this hypothesis. Although numerous archaeological traces of human activity in the Grabia River valley and in the vicinity of Ldzań mire, especially related to the Funnel Beaker Culture settlements of the Middle Neolithic (Pelisiak, 2004; Pelisiak \& Kamiński, 2004), have been noted, the effects of human pressure on the natural ecosystem of Ldzań was probably negligible. Other investigation in the lower part of Grabia River valley (Pawłowski et al., 2014) also suggests occasional human penetration into this part of the valley. This situation is not unique, because the specific settlement preferences, and the significant changes in these preferences in river valleys where there is good access to water resources, are difficult to interpret, and their role changes over time. Additionally, the lack of precise age assignments for the Ldzań samples from specific depths also hampers determination of the exact chronology of the history of human activity. Therefore, we cannot rule out the possibility of human impact on the evolution of the environment in Grabia River valley. The relatively low mineral content adjacent to cores L2, L7, and (partly) L8, near the escarpment of the mire (Figs. 9, 10) may indicate a negligible supply of MM from the slope, including transport and aeolian processes. The lack of a rapid increase in MM content suggests relative slope stability during the existence of the mire. The deluvial deposit washed out from the slope of the higher terrace (Fig. 2A) is limited to this one place, so this type of redeposition can be regarded as quite insignificant.

The degree of peat decomposition partly confirms the above-mentioned changes. The peat in upper part cores located closer to the escarpment is poorly decomposed. This may indicate low-oxygenation conditions, slow biological transforma- tions and strong waterlogging during accumulation of these sediments. This situation is connected with the presence of groundwater as a result of the location within the zone of groundwater discharge at the foot of the valley side. Plant structure in peat is distinct and these organic deposits are fibric. There was no secondary transformation of organic matter which occurs after drying peat bogs (Drzymulska, 2003; Truba \& Oleszczuk, 2014).

In turn, the increase in the degree of peat decomposition in the lower and marginal parts of the mire is the result of the oxygenation of the surface peat layer, and shows that the accumulation of peat occurred at least periodically under dried conditions, probably due to the seasonal influence of flooding (which has an impact on drying and moistening of the mire), the incision of the river channel, and the reduction in the groundwater table, or a combination of these factors. Such situations could also promote water table fluctuations and degree of peat decomposition. Such spatial variation in the $\mathrm{OM}$ content is compatible with the cores' location with respect to the Grabia River (Fig. 9).

Some tendencies in Ldzań mire development may have been driven by other external factors, such as climate change. Cooling and warming influenced peat accumulation and were also responsible for peatland vegetation and productivity (Van Bellen et al., 2011). However, the lack of radiocarbon dates from the Ldzań mire obscures the determination of such periods, as well as the presence of hiatuses. For this reason, these changes are not discussed here.

\section{Final remarks}

The parameters of the biogenic sediments studied confirmed that the peats are among the most heterogeneous sediments. The Ldzan mire generally receives water through overland drainage. Changes in peatland vegetation, hydrology, and, probably, climate were likely to have been important during its development. This complexity, especially of the water economy, is well reflected in the physicochemical properties of the peats. The long-term vertical changes in $\mathrm{pH}$ and $\mathrm{OM}$, and their intensities across cores, show the influence of site-specific factors and local ecosystem complexity. The comparison of these properties across the cores allows the lateral and vertical correlation of these phenomena across the mire. The presence of groundwater seems be the most important factor that influences peat-forming phytocoenoses development. Ldzań represents a rheotrophic mire, 
where there is a through-flow of groundwater. This is especially visible in the central and eastern parts of the mire, with a far more limited supply of MM than in the flood-fed parts. The river's influence, especially from the SW part of the mire, led to an increase in the value of the $\mathrm{pH}$ and MM content. Geostatistical modelling provides an opportunity to interpolate and simulate the physicochemical variables at unsampled locations of the mire and thus obtain the possibly best spatial grid models of the $\mathrm{pH}$ and $\mathrm{MM}$ distribution between cores. The resultant grid models relating to the elevation-distance sections show that changes in $\mathrm{MM}$, as well as in $\mathrm{pH}$, may be indicative of different types of mire supply. Moreover, the 3D-grid models allow to recognise some characteristic geometric features in the vertical and horizontal patterns of the physicochemical parameters of mire. In our work we recognised lens-shaped and fan-like features clearly related with the mire supply by groundwater and flooding. This geostatistical modelling thus seems be a good starting tool for estimating the vertical and horizontal patterns of the physicochemical parameters of mire sediments and ecosystem development.

\section{Acknowledgements}

We are grateful to two reviewers for critical and helpful comments. This study was supported by a grant from the National Science Centre (NCN), no. 2011/01/B/ST10/04905. We express our gratitude to the Head Office of Geodesy and Cartography in Poland for the possibility of using and publishing the LiDAR data in the present study; such data are protected by copyright of Polish law (Dz.u.2010, no 193, pos.1287). We also thank G.Wigowska for technical assistance.

\section{References}

Atkinson, P.M. \& Lloyd, C.D. (Eds), 2009. GeoENV VII Geostatistics for Environmental Applications. Springer, 419 pp.

Bauer, I. E., Gignac, L. D. \& Vitt, D. H., 2003. Development of a peatland complex in boreal western Canada: Lateral site expansion and local variability in vegetation succession and long-term peat accumulation. Canadian Journal of Botany 81, 833-847.

Beilman, D. W., Vitt, D. H. Bhatti, J. S. \& Forest, S., 2008. Peat carbon stocks in the southern Mackenzie River Basin: Uncertainties revealed in a high-resolution case study. Global Change Biology 14, 1221-1232.

Blodau, Ch. \& Moore, T.R., 2003. Micro-scale CO2 and $\mathrm{CH} 4$ dynamics in a peat soil during a water fluctua- tion and sulfate pulse. Soil Biology E Biochemistry 35, 535-547.

Borren, W. \& Bleuten, W., 2004. 3D dynamic modelling of Holocene and 21st century carbon accumulation by a large West Siberian peat bog comlex. [In:] J.Paivanen (Ed.), Wise use of peatland. $12^{\text {th }}$ International Peat Congress, Tampere, Finland, 109-114.

Borren, W. \& Bleuten, W., 2006. Simulating Holocene carbon accumulation in a western Siberian watershed mire using a three-dimensional dynamic modeling approach. Water Resources Research 42, W12413.

Borren, W. \& Bleuten, W., 2014. Carbon flux changes after draining part of the bakchar bog: a 3-d dynamic modeling approach. [In:] A.A. Titlyanowa \& M.I. Dergacheva (Eds): West Siberian peatlands and carbon cycle: past and present. Proceedings of Fourth International Field Symposium, Novosibirsk, Russia, 138.

Bos, I.J., Busschers, F.S. \& Hoek, W.Z., 2012. Organic-facies determination: a key for understanding facies distribution in the basal peat layer of the Holocene Rhine-Meuse delta, The Netherlands. Sedimentology 59, 679-703.

Cardellini, C., Chiodini, G. \& Frondini, F., 2003. Application of stochastic simulation to $\mathrm{CO} 2$ flux from soil: Mapping and quantification of gas release. Journal of Geophysical Research 108, 2425.

Chapman, S. J., Bell, J. Donnelly, D.\& Lilly, A., 2009. Carbon stocks in Scottish peatlands. Soil Use and Management 25, 105-112.

Charifo, G., Almeida, J.A. \& Ferreira, A., 2013. Managing borehole samples of unequal lengths to construct a high-resolution mining model of mineral grades zoned by geological units. Journal of Geochemical Exploration 132, 209-223.

Clymo, R.S., 1978. A model of peat bog growth. [In:] Heal, O.W., Perkins, D.F. (Eds): Production Ecology of British Moors and Montane Grasslands. Springer, Berlin, 183-223.

Clymo, R. S., Turunen, J. \& Tolonen, K. 1998. Carbon accumulation in peatland. Oikos 81, 368-388.

Dell'Arciprete, D., Bersezio, R., Felletti, F., Giudici, M., Comunian, A. \& Renard, P., 2012. Comparison of three geostatistical methods for hydrofacies simulation: a test on alluvial sediments. Hydrogeology Journal 20, 299-311.

Cohen, K.M., 2005. 3D Geostatistical interpolation and geological interpretation of palaeo-groundwater rise in the Holocene coastal prism in the Netherlands. In: Giosan, L. \& Bhattacharya, J.P. (Eds), River deltas Concepts, models, and examples. SEPM Special Publication, 83, 341-364.

Dembek, W. \& Oświt, J., 1992. Rozpoznawanie warunków hydrologicznego zasilania siedlisk mokradłowych. [Identification of the hydrological feed conditions of the mire habitats]. Biblioteka Wiadomości Instytutu Melioracji i Użytków Zielonych 79, 15-38 (in Polish)

Deutsch, C.V. \& Journel, A.G., 1992. GSLIB: Geostatistical Software Library and User's Manual. Oxford University Press, New York, 448 pp.

Domińczak, P. \& Okupny, D., 2010. Przestrzenne zróżnicowanie wybranych właściwości fizykoche- 
micznych osadów biogenicznych torfowiska Kopanicha koło Skierniewic. [Spatial variability of selected physicochemical properties of biogenic sediments in the Kopanicha peatland near Skierniewice]. [In:] R. Twardosz \& W. Ziaja (Ed.): Prace Geograficzne, Jagiellonian University, Kraków, 99-110 (in Polish)

Dobrowolska, B., 2006. Analiza struktury i przeciętnego poziomu cechy. [In]: W. Starzyńska (Ed.): Podstawy statystyki [Statistical principles] Warszawa, Wydawnictwo Difin, 86-124 (in Polish)

Dobrzański, B. \& Zawadzki, S., 1995. Gleboznawstwo [Pedology]. Powszechne Wydawnictwo Rolnicze i Leśne, Warszawa. (in Polish) 561 pp.

Drzymulska, D., 2003. Znaczenie analizy subfosylnych makroszczątków roślinnych i stopnia rozkładu torfu dla rekonstrukcji paleośrodowiska. [The importance of subfossil plant remnants and peat decomposition degree analyses for paleoenvironment reconstruction]. Kosmos. Problemy Nauk Biologicznych 52, 299-306 (in Polish)

Forysiak J., Obremska M., Pawłowski D. \& Kittel P., 2010. Late Vistulian and Holocene changes in the Ner river valley in light of geological and palaeoecological data from the Ner-Zawada Peatland. Geologija, 52, 25-33.

Forysiak, J., Kloss, M. \& Żurek, S., 2012. Wstępna charakterystyka geologiczna i paleobotaniczna torfowiska Wilczków. [Preliminary geological and palaeobotanical characterization of Wilczków mire] Studia Limnologica et Telmatologica 6, 95-101 (in Polish)

Frankiewicz, J.K., 1980. Surowce mineralne świata. Torf [Mineral resources of the world. Peat] Wydawnictwa Geologiczne, Warszawa, 9-46 (in Polish)

Gao, Y., Wang, Y., Zhang, G., Xia, J., Mao, L., Tang, Z. \& Zhou, P., 2012. An approach for assessing soil health: a practical guide for optimal ecological management. Environmental Earth Sciences 65, 153-159.

Goovaerts, P., 1999. Geostatistics in soil science: state-ofthe-art and perspectives. Geoderma 89, 1-45.

Goovaerts, P., 2000. Estimation or simulation of soil properties? An optimization problem with conflicting criteria. Geoderma 97, 165-186.

Goovaerts, P., 2001. Geostatistical modelling of uncertainty in soil science. Geoderma 103, 3-26.

He, Y., Hu, K.L., Chen, D.L., Suter, H.C., Li, Y., Li, B.G., Yuan, X.Y. \& Huang, Y.F., 2010. Three dimensional spatial distribution modeling of soil texture under agricultural systems using a sequence indicator simulation algorithm. Computers and Electronics in Agriculture 715, S24-S31.

Hengl, T., 2006. Finding the right pixel size. Computers and Geosciences 32, 1283-1298.

Hengl, T., 2009. A Practical Guide to Geostatistical Mapping. $2^{\text {nd }}$ ed. University of Amsterdam, Amsterdam, $291 \mathrm{pp}$.

Ilnicki, P., 2002. Torfowiska $i$ torf [Peatlands and peat]. Wydawnictwo Akademii Rolniczej, Poznań. (in Polish) $606 \mathrm{pp}$.

Ingram, H.A.P., 1982. Size and shape in raised mire ecosystems: a geophysical model. Nature 297, 300-303.

Isaaks, E.H. \& Srivastava, R.M., 1989. An Introduction to Applied Geostatistics. Oxford University Press, New York, 592 pp.
Jones, L.S. \& Harper, J.T., 1998. Channel avulsions and related processes, and large-scale sedimentation patterns since 1875, Rio Grande, San Juis Valley, Colorado. Geological Society of America Bulletin 110, 411-421.

Kaufhold, S., 2007. Carbonates. [In:] K. Knodel, G. Lange \& H.J. Voigt (Eds): Environmental geology - handbook of field methods and case studies. Springer, Berlin, Heidelberg, 862-867.

Keaney, A., McKinley, J., Graham, C., Robinson, M. \& Ruffell, A., 2013. Spatial statistics to estimate peat thickness using airborne radiometric data. Spatial Statistics 5, 3-24.

Klatkowa, H., 1987. Szczegótowa Mapa geologiczna Polski 1:50 000, ark. Łask [Detailed Geological Map of Poland 1:50,000, Łask sheet]. Polski Instytut Geologiczny, Warszawa, 1-54.

Korhola, A., Alm, J. Tolonen, K., Turunen, J. \& Jungner, H., 1996. Three-dimensional reconstruction of carbon accumulation and $\mathrm{CH}_{4}$ emission during nine millennia in a raised mire. Journal Quaternary Sciences 11, 161-165.

Korhola, A., M. Ruppel, H. Seppä, M. Väliranta, T. Virtanen, \& Weckström, J., 2010. The importance of northern peatland expansion to the late Holocene rise of atmospheric methane. Quaternary Sciences Review 29, 611-617.

Kozakiewicz, A., 1962. Charakterystyka substancji organicznej gleb torfowych i torfów torfowisk dolinowych. [Characteristics of organic matter of peat soils and peat of valley mires] Roczniki Gleboznawcze, 11, 73-100 (in Polish)

Krivoruchko, K., 2011. Spatial Statistical Data Analysis for GIS Users. Esri Press, Redlands, 894 pp.

Kwiatkowski, A., 1971. Nieorganiczne składniki torfu. [Inorganic components of peat] Biuletyn Informacyjny Torf 4, 31-43 (in Polish)

Lin, Y.P., Chang, T.K. \& Teng, T.P., 2001. Characterisation of soil lead by comparing sequential Gaussian simulation, simulated annealing simulation and kriging methods. Environmental Geology 41, 189-199.

Maciak, F. \& Liwski, S., 1996. Ćwiczenia z torfoznawstwa. [Peat deposits exercises] Szkoła Główna Gospodarstwa Wiejskiego, Warszawa, 1-128 (in Polish)

Maksimow, A., 1965. Torf i jego użytkowanie w rolnictwie [Peat and its use in agriculture]. Państwowe Wydawnictwo Rolnicze i Leśne, Warszawa, 396 pp. (in Polish)

Maksymiuk, Z., 1970. Hydrografia dorzecza Grabi [Hydrography of Grabia River valley] Acta Geographica Lodziensa 25, 1-102 (in Polish)

Mäkilä, M., \& Moisanen, M., 2007. Holocene lateral expansion and carbon accumulation of Luovuoma, a northern fen in finnish Lapland. Boreas 36, 198-210.

Miller, H.J. 2004. Tobler's first law and spatial analysis. Annals of the Association of American Geographers 94, 284-289.

Myślińska, E., 1999. Parametry fizyczne torfów i ocena metod ich oznaczania. [Physical properties of peats and evaluation of methods of their determination]. Przeglad Geologiczny 47, 676-682. (in Polish) 
Myślińska, E., 2001. Grunty organiczne i laboratoryjne meto$d y$ ich badania [Organic soils and laboratory methods of research]. PWN, Warszawa, 1-208 (in Polish)

Okruszko, H., 1964. Czynniki hydrologiczne jako podstawa podziału torfowisk. [Hydrological factors as the basis for the distribution of peatlands] Wiadomości Instytutu Melioracji i Użytków Zielonych 4, 147-164 (in Polish)

Okruszko, H., 1976. Zasady rozpoznawania i podziału gleb hydrogenicznych $z$ punktu widzenia potrzeb melioracji [Principles of recognition and distribution of hydrogenic soils from the melioration point of view]. Biblioteka Wiadomości Instytutu Melioracji i Użytków Zielonych 52, 7-53 (in Polish)

Okruszko, H., 1979. Mokradła i ich klasyfikacja w Polsce [Wetlands and their classification in Poland]. Biuletyn Informacyjny Torf 2, 61, 49-58 (in Polish)

Okruszko, H., 1991. Zasady nawożenia gleb torfowych [Rules fertilization of peat soils]. Biblioteka Wiadomości Instytutu Melioracji i Użytków Zielonych 77, 87-103 (in Polish)

Okruszko, H., 1994. System of hydrogenic soil classification used in Poland. Biblioteka Wiadomości Instytutu Melioracji i Użytków Zielonych 84, 5-27 (in Polish)

Okupny, D., Fortuniak, A. \& Tomkowiak J., 2013. Pionowa zmienność składu chemicznego osadów biogenicznych torfowiska Podwódka (Kotlina Szczercowska). [Vertical variability of biogenic sediment geochemistry in the Podwódka peatland (the Szczerców Basin). [In:] R.K., Borówka, A. Cedro \& I. Kavetskyy (Eds): Wspótczesne problemy badań geograficznych [Contemporary problems of geographical studies]. Szczecin, 83-92 (in Polish)

Olea, R.A., Troy, A.C. \& Coleman, J.L., 2010. A methodology for the assessment of unconventional (continuous) resources with an application to the Greater Natural Buttes Gas Field, Utah. Natural Resources Research 19, 237-251.

Oświt, J., Pacowski, R., Żurek, S., 1976. Characteristics of more important peat species in Poland. [In:] Peatlands and their utilization in Poland. Proceedings of 5 th International Peat Congress, Poznań-Warszawa, Poland, 316-320.

Oświt, J., Żurek, S. \& Liwski, S., 1980. Stosunki glebowe doliny Śliny na tle warunków wodnych. [Soil conditions in the Ślina River valley against the background of water conditions]. Zeszyty Problemowe Postęów Nauk Rolniczych 234, 159-195 (in Polish)

Paivanen, J., 1973. Hydraulic conductivity and water retention in peat soils. Acta Forestalia Fennica 129, 1-70.

Parsekian, A.D., Comas, X., Slater, L. \& Glaser P.H., 2011. Geophysical evidence for the lateral distribution of free phase gas at the peat basin scale in a large northern peatland. Journal of Geophysical Research 116, G03008.

Pawłowski, D., Kloss, M., Obremska, M., Szymanowski, M. \& Żurek, S., 2012. Evolution of small valley mire in central Poland as a result of hydroclimatic oscillations. Geochronometria 39, 133-148.

Pawłowski, D., Milecka, K., Kittel, P., Woszczyk, M. \& Spychalski, W., 2014. Palaeoecological record of natu- ral changes and human impact in a small river valley in Central Poland. Quaternary International (in press): http:/ / dx.doi.org/10.1016/j.quaint.2014.06.033

Pelisiak, A., 2004. Osadnictwo kultury pucharów lejkowatych w dorzeczu Grabi (Polska środkowa). Uwarunkowania środowiskowe [In:] D. Abłamowicz \& Z. Śnieszko (Eds): Zmiany środowiska geograficznego $w$ dobie gospodarki rolno-hodowlanej. Studia z obszaru Polski [Geographical Environment Changes in the Period of Farming and Breeding Economy. Studies from Poland's Area]. Katowice, 171-183 (in Polish with English summary)

Pelisiak, A. \& Kamiński, J., 2004. Geneza i wiek osadów w dolinie Grabi na stanowisku Ldzań w świetle osadnictwa pradziejowego środowiskowe [Origin and chronology of the sediments in the site at the Ldzan in the Grabia valley in a light of prehistoric settlement]. [In:] D. Abłamowicz \& Z. Śnieszko (Eds): Zmiany środowiska geograficznego w dobie gospodarki rolno-hodowlanej. Studia z obszaru Polski [Geographical Environment Changes in the Period of Farming and Breeding Economy. Studies from Poland's Area]. Katowice, 184-196 (in Polish with English summary)

Pniewski, M., Gottschalk, L., Krasovskaia, I. \& Chormański, J., 2012. A GIS-based model for testing effects of restoration measures in wetlands: A case study in the Kampinos National Park, Poland. Ecological Engineering 44, 25-35.

Pyrcz, M.J. \& Deutsch, C.V., 2014. Geostatistical Reservoir Modelling. Second Edition. Oxford University Press, New York, 448 pp.

Remy, N., Boucher, A. \& Wu, J., 2009. Applied Geostatistics with SGEMS. A User's Guide. Cambridge University Press, New York, 286 pp.

Robertson, G.P., Crum, J.R. \& Ellis, B.G., 1993. The spatial variability of soil resources following long-term disturbance. Oecologia 96, 451-456.

Ruggeri, P., Gloaugen, E., Lefebre, R., Irving, J. \& Holliger, K., 2014. Integration of hydrological and geophysical data beyond the local scale: Application of Bayesian sequential simulation to field data from the Saint-Lambert-de-Lauzon site, Quebec, Canada. Journal of Hydrology 514, 271-280.

Rühle, E., 1973. Metodyka badań osadów czwartorzędowych [The research methodology of Quaternary sediments]. Wydawnictwa Geologiczne, Warszawa. (in Polish)

Rydelek, P., 2011. Geneza i skład części mineralnych wybranych złóż torfów niskich Wysoczyzny Lubartowskiej [Origin and composition of mineral particles of selected peat deposits in Lubartowska Upland]. Woda-ŚrodowiskoObszary Wiejskie, Falenty, 11, 135-149. (in Polish)

Saito, H., Yoshino, K., Ishida, T., Nagano, T., Sirichuaychoo, W., Jongskul, A. \& Haraguchi, N., 2005. Geostatistical estimation of tropical peat-soil volume at Bacho, Thailand: impact of spatial support size and censored information. Geoderma 125, 235-247.

Sheng, Y., Smith, L.C. MacDonald, G. M., Kremenetski, K.V., Frey, K.E., Velichko, A.A., Lee, M., Beilman, D.W. \& Dubinin, P., 2004. A high resolution GISbased inventory of the west Siberian peat carbon pool. Global Biogeochemical Cycles 18, GB3004. 
Smith, D.G. \& Pearce, C.M., 2002. Ice jam-caused fluvial gullies and scour holes on northern river flood plains. Geomorphology 42, 85-95.

Szajdak, L., 2002. Właściwości chemiczne torfu. [Chemical properties of peat]. [In.] P. Ilnicki (Ed.): Torfowiska i torf [Peatlands and peat]. Wydawnictwo Akademii Rolniczej, Poznań, 432-449 (in Polish).

Szymanowski, M., 1993. Podstawowe właściwości fizyczno-wodne i retencyjne oraz ich zależności od gęstości objętościowej różnych utworów słabo zamulonych (niskopopielnych). [Basic physico-chemical properties and water retention, and their dependence on bulk density of different unsiletd sediments] Wiadomości Instytutu Melioracji i Użytków Zielonych 17, 153-174. (in Polish)

Tobolski, K., 2000. Przewodnik do oznaczania torfów i osadów jeziornych [Guide for the determination of peat and lake sediments]. Vademecum Geobotanicum, Wydawnictwo Naukowe PWN. (in Polish) 508 pp.

Tobolski, K., 2003. Torfowiska na przykładzie Ziemi Świeckiej [Ziemia Świecka peatlands]. Towarzystwo przyjaciół Dolnej Wisły, Świecie. (in Polish) 255 pp.

Tobolski, K., 2005a. Niektóre metody badań laboratoryjnych. [Laboratory testing methods]. [In:] G. Miotk-Szpiganowicz, K. Tobolski \& J. Zachowicz (Eds): Osady zbiorników akumulacji biogenicznej. Przewodnik do prac laboratoryjnych i terenowych. [Depostis of the biogenic accumulation reservoirs. Guide-book for laboratory and field activity]. Polish Geological Institute, Gdańsk, 68-71.

Tobolski, K., 2005b. Środowiska akumulacji biogenicznej $\mathrm{w}$ jeziorach i torfowiskach. [Biogenic accumualation environemnts in lakes and peatlands]. [In:] G. Miotk-Szpiganowicz, K. Tobolski \& J. Zachowicz (Eds): Osady zbiorników akumulacji biogenicznej. Przewodnik do prac laboratoryjnych i terenowych. [Depostis of the biogenic accumulation reservoirs. Guide-book for laboratory and field activity]. Polish Geological Institute, Gdańsk, 34-42.

Truba, M. \& Oleszczuk, R., 2014. An analysis of some basic chemical and physical properties of drained fen peat and moorsh soil layers. Annals of Warsaw University of Life Sciences - SGGW. Land Reclamation 46, 69-78.

Turkowska, K., 1988. Rozwój dolin rzecznych na Wyżynie Łódzkiej w późnym czwartorzędzie [Development of the Łódź Upland valleys in the Late Quaternary]. Acta Geographica Lodziensia 57, 157 pp (in Polish).

Turkowska, K., 2006. Geomorfologia region tódzkiego [Geomorphology of the Eódz region]. Wydawnictwo Uniwersytetu Łódzkiego, 238 pp (in Polish).

Van Bellen, S., P.-L. Dallaire, M. Garneau, \& Bergeron, Y., 2011. Quantifying spatial and temporal Holocene carbon accumulation in ombrotrophic peatlands of the Eastmain region, Quebec, Canada. Global Biogeochemical Cycles 25, GB2016.
Van Gelder, A., Van den Berg, J.H., Cheng, G. \& Xue, C., 1994. Overbank and channelfill deposits of the modern Yellow River delta. Sedimentary Geology 90, 293-305.

Watts, D.L., Cohen, M.J., Heffernan, J.B. \& Osborne, T.Z., 2010. Hydrologic modification and the Loss of self-organized patterning in the ridge-slough mosaic of the Everglades. Ecosystems 13, 813-827.

Webster, R. \& M. Oliver, 2007. Geostatistics for Environmental Scientists. John Wiley, Chichester, UK, 330 pp.

Weerts, H.J.T. \& Bierkens, M.F.P., 1993. Geostatistical analysis of overbank deposits of anastomosing and meandering fluvial systems; Rhine-Meuse delta, Netherlands. Sedimentary Geology 85, 221-232.

Woszczyk, M. \& Szczepaniak, M., 2008. Reevaluation of the Scheibler method and its usefulness in the analysis of carbonate content in lake sediments. [In:] E. Bajkiewicz-Grabowska \& D. Borowiak (Eds): Antropogenic and natural transformations of lakes, 2, 223-226.

Wójcicki, K.J., 2007. Zawartość materii organicznej w osadach zbiornikowych jako wskaźnik dynamiki procesów geomorfologicznych - przykłady z dorzecza górnej Odry.[The content of organic matter in basin deposits as an indicato of the dynamic of geomorphic processes - the causes from the upper Odra basin]. [In:] E. Smolska, D. Giriat (Eds): Rekonstrukcja dynamiki i procesów geomorfologicznych - formy rzeźby i osady [Reconstruction of morphological process dynamics - landforms and deposits]. Uniwersytet Warszawski, 445-455. (in Polish)

Wójcicki, K.J., 2013. Osady biogeniczne w środowisku depozycyjnym starorzeczy (warunki akumulacji $i$ wymowa paleośrodowiskowa na przykładach z dorzecza górnej Odry) [Biogenic sediments in abandoned River channel: their deposition environment and significance in peleoenvironmental studies based on the examples from the Upper Odra catchment, Southern Poland]. Uniwersytet Śląski, Katowice. (in Polish) 240 pp.

Yu, Z., Campbell, I.D., Vitt, D.H. \& Apps, M.J., 2001. Modelling long-term peatland dynamics. I. Concepts, review, and proposed design. Ecological Modelling 145, 197-210.

Zapata-Rios, X., Rivero, X.R., Naja, G.M. \& Goovaerts, P., 2012. Spatial and temporal phosphorus distribution changes in a large wetland ecosystem, Water Resources Research 48, W09512.

Żurek, S., 1993. Zmiany paleohydrologiczne w mokradłach. [Paleohydrological changes in the wetlands]. Przeglad Geograficzny 64, 75-95 (in Polish).

Żurek, S., 2006. Katalog rezerwatów przyrody na torfowiskach Polski [Catalog of peatland nature reserves in Poland]. Wydawnictwo Akademii Świętokrzyskiej, Kielce. (in Polish) 288 pp.

Manuscript submitted 8 October 2014 Revision accepted 4 December 2014 